Diana Xiao En Liu, BA, University of Toronto, 2009

\author{
A Major Research Paper \\ Presented to Ryerson University \\ In partial fulfillment of the requirements for the degree of \\ Master of Arts \\ in the Program of \\ Immigration and Settlement Studies
}

Toronto, Ontario, Canada, 2010

(C) Diana Xiao En Liu 2010 
I hereby declare that I am the sole author of this major research paper.

I authorize Ryerson University to lend this paper to other institutions or individuals for the purpose of scholarly research.

I further authorize Ryerson University to reproduce this paper by photocopying or by other means, in total or in part, at the request of other institutions or individuals for the purpose of scholarly research. 


\title{
REGULARIZATION OF THE UNDOCUMENTED IN CANADA: LESSONS FROM EUROPE AND THE UNITED STATES
}

\author{
(C) Diana Xiao En Liu, 2010 \\ Master of Arts \\ Immigration and Settlement Studies \\ Ryerson University
}

\begin{abstract}
$\underline{\text { Abstract }}$
During the past decade, the number of undocumented people has been by far the most rapidly rising immigrant population worldwide. In Canada, the number of individuals living without a legal status is estimated around 200,000 to 600,000 . Therefore, this issue has become increasingly difficult for governments to ignore. Many countries around the world have implemented regularization programs as policy solutions to the issue of undocumented people residing within their borders. This study examines the different criteria and reasons based on which countries in Europe, the United States, and Canada have implemented or proposed regularization programs. The aim is to propose possible regularization criteria and options that Canada could take into consideration as policy solutions to deal with the undocumented residents currently in the country.
\end{abstract}

Key Words: Regularization; Undocumented migrants; Canada; Europe; United States 


\section{Acknowledgements}

I am very thankful to my advisor and supervisor, Arthur Ross, for his thoughtful suggestions and guidance throughout my writing process, and for challenging me to think deeply about this issue. I am also grateful for the practical inputs and insights of my second reader, Harald Bauder.

I am eternally grateful for the love and support of my God, parents, and friends, and the encouragement I have received from them that has seen me through my studies. 


\section{Table of Contents}

Chapter 1: Introduction

Chapter 2: Non-status Immigrants in Canada

Chapter 3: Regularization Criteria in Europe and the US..........................................12

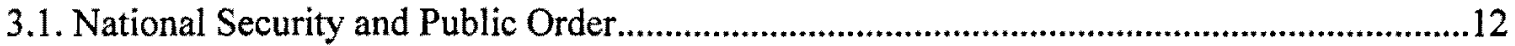

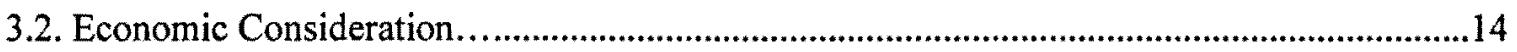

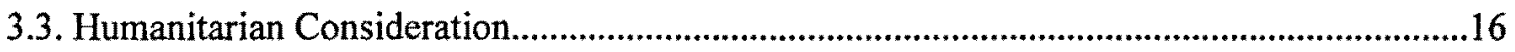

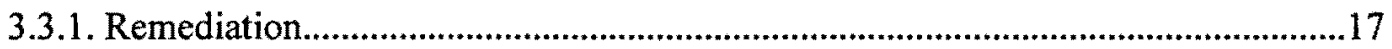

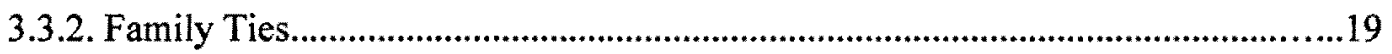

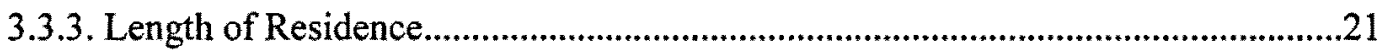

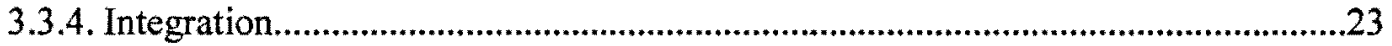

3.3.5. Victims of Human Trafficking.......................................................................25

3.3.6. Medical Condition............................................................................................26

Chapter 4: Regularization: The Case of Canada...................................................................28

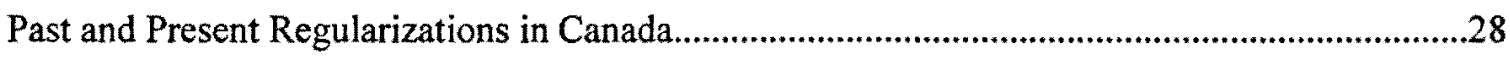

Chapter 5: Criteria for Regularization in Canada Compared to the EU and US................35

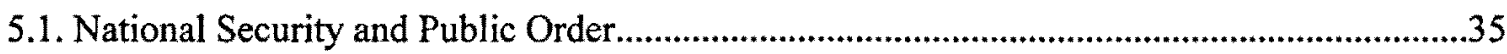

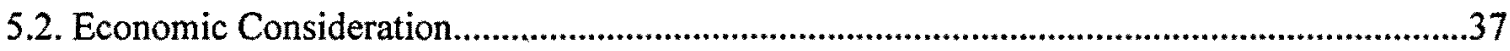

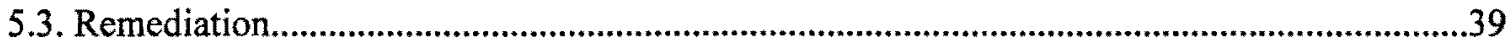

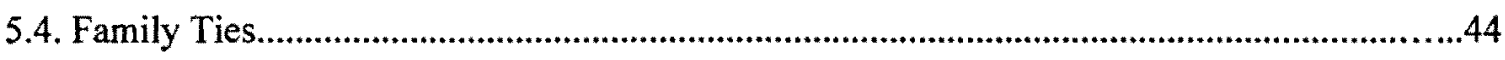

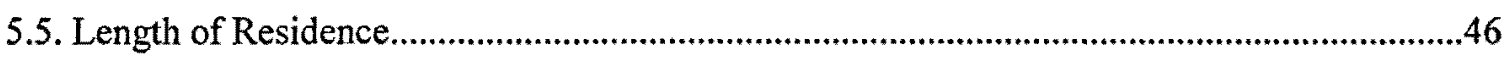

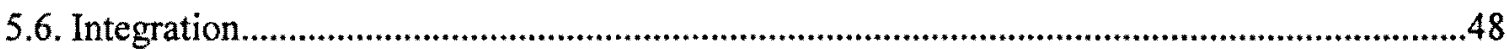




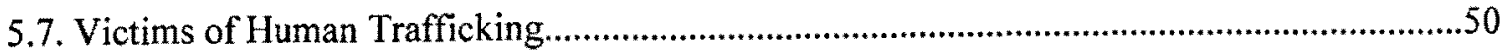

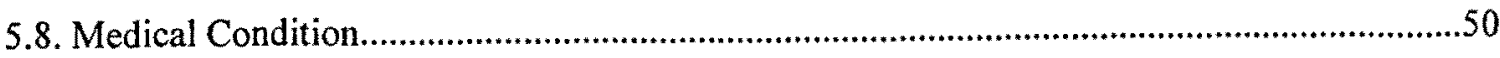

Chapter 6: Conclusion 


\section{Chapter 1: Introduction}

One of the most contentious and polemical issues in the politics of immigration that states have to deal with is the population of people that have settled on their soil without formal authorization. The phenomenon of undocumented migration is not new and has been growing internationally over the years. According to quantitative analysis by credible entities such as the Organisation for Economic Cooperation and Development (OECD) and the United Nations Department of Economic and Social Affairs (UNDESA), the undocumented or non-status flow of people has been by far the most rapidly rising single form of international migration during the past decade (Sunderhaus, 2007). It is estimated that currently there are 30 to 40 million people with uncertain legal status worldwide (Cohen, 2009a; Magalhaes, Carrasco, \& Gastaldo, 2010). The largest population of undocumented immigrants resides in the US, roughly 10 to 11 million people (Papademetriou, 2005a). In Europe, there are approximately 7 to 8 million non-status immigrants (Papademetriou, 2005a). In the case of Canada, estimates of the number of people living without a legal status range from 200,000 to 600,000 (Jimenez, 2003; Robertson, 2005; Bernhard, \& Young, 2009; Magalhaes et al., 2010). Therefore, governments find it increasingly difficult to ignore the issue, since the presence of these undocumented migrants has far-reaching implications and affects almost all major policy fields (Sunderhaus, 2007).

There are two main policy approaches to this problem. On the one hand, unauthorized immigrants are seen as "law breakers" or "queue jumpers" (CIC, 2008). Anti-immigration groups argue that in order to maintain the integrity of the immigration system, non-status residents should be expelled. However, large-scale deportations are highly controversial and increasingly impossible due to ethical, practical, and legal barriers. In addition, they are extremely costly, can be socially and economically disruptive, and may have serious humanitarian effects (Papdemetriou, 2005a; Sunderhaus, 2007). Furthermore, Cohen (1994) argues that deportation of long-term residents regardless of legal status violates principles of fundamental justice such as liberty and security of the person stated in section 7 of the Canadian Charter of Rights and Freedoms. 
A second policy approach is the implementation of regularization or legalization programs. They are programs that "allow non-status immigrants to apply for official legal status" (Khandor et al., 2004, p.7). Sunderhaus (2007) points out the importance of ensuring a broad and flexible definition of legalization that includes "all policy measures that in the end lead to regularization rather than focusing only on obvious and direct forms of regularization" (p.75). Regularization can be problematic and has its pitfalls. It is often perceived as rewarding "law breakers" and encouraging further illegal migration. Despite of its complexity, regularization programs have emerged in the past 25 years or so as a prominent public policy mechanism for immigration management (Papdemetriou, 2005a). States use them to account for and manage the undocumented population in their countries, and they tend to be implemented in concert with internal and external reinforcement of migration controls such as tightening border and visa controls (Levinson, 2005). Those in favour of regularization argue that it reduces the size of the clandestine population, the underground economy and consequently the exploitation of undocumented workers. It also enables states to gain awareness and control over non-status populations, has a positive impact on tax revenues, and most importantly, enhances the human rights and human dignity of those in an irregular situation (Greenway, 2007; Kraler, \& Baldwin-Edwards, 2009).

In Canada, an application for Humanitarian and Compassionate $(\mathrm{H} \& \mathrm{C})$ consideration is the only currently available pathway for undocumented immigrants in Canada to have their status regularized; however, due to a number of limitations and shortcomings indicated and demonstrated throughout the paper, particularly in Chapter 4, it is questionable whether this option addresses the issue effectively. Moreover, the current Canadian government stance on undocumented immigrants acknowledges their precarious status, but it does not go further to propose concrete solutions to the problem. In chapter 2, a report on the non-status workers by the Standing Committee on Citizenship and Immigration will help explain the Federal government's stance on this issue. However, policy inaction in this area is often justified by the government because it is concerned about the implications of implementing a regularization program and at the same time maintaining the integrity of the immigration system. Therefore, the purpose of this paper is to propose possible regularization criteria and options that Canada 
could take into consideration as policy solutions for the problem of the non-status population living in the country. Along with the implementation of regularization programs, the integrity of the immigration system could be balanced with enactments of stricter exit controls, enforcement of removal orders, remediation of systemic flaws in immigration laws and programs, and complying with upholding human rights and humanitarian considerations.

This paper will examine regularization options using an empirical approach, by summarizing and analyzing the different criteria and reasons that countries such as the United States and in Europe have used to develop their past and recent regularization programs and proposals. Each of the analyzed regularization criteria will be compared to the case of Canada. The first section of this paper will identify undocumented or non-status individuals in Canada. In order to proceed with a discussion of options and criteria to regularize their status, it is important to identify who they are, the reasons for their lack or loss of status, and their living and working conditions in the absence of legal rights and protections. This general overview will help to understand commonly held assumptions and beliefs about who undocumented residents are and what they are doing in Canada.

Section two will explore the different criteria considered for regularization programs and proposals in the US and parts of Europe. It is important to note that these are not regularization models to be followed by Canada, but they serve to suggest possible policy options. Therefore, each criterion will be analyzed to determine if it is applicable in the Canadian case.

The final part of this paper will focus on regularization initiatives to deal with undocumented people in Canada. The first part will examine the implementation of past and present regularization criteria and programs. A historical approach to the issue will provide important lessons, guidelines and tentative policy insights for present and future consideration. Part two will compare the case of Canada to the regularization criteria applied and proposed in Europe and the US. The comparison will incorporate existing and past regularization programs, and more recent proposals that contain possible legalization criteria suggested by pro-regularization campaigns in Canada. 


\section{Chapter 2: Non-status Immigrants in Canada}

The precise number of non-status immigrants in Canada is difficult to establish, but estimates range from about 200,000 to 600,000 and they include people from different age groups and backgrounds (Jimenez, 2003; Robertson, 2005; Bernhard, \& Young, 2009; Magalhaes et al., 2010). This wide range of estimates is due to the difficulty of calculating the exact number of undocumented immigrants in Canada since by the very nature of being undocumented, official statistics cannot be produced. Nevertheless, what the government could do to provide with a closer estimate is by enforcing exit controls. As stated in the May 2008 Auditor General Report, "due in part to a lack of exit controls, there is a growing number of individuals whose whereabouts is unknown and who might remain in Canada illegally" (Auditor General, 2008).

Many pathways lead to the loss of legal status in Canada. Unlike the United States, where the main source of large-scale unauthorized immigration is from unauthorized cross-border migration, this is less of a phenomenon in Canada due to its geographic realities (Goldring, Berinstein, \& Bernhard, 2009). In fact, the Border Services Agency reports that Canada's border enforcement "focuses on goods, arms and 'fugitive criminals"' (Goldring et al., 2009, p.246), rather than on undocumented migrants crossing borders. Instead, a recently released report by the Standing Committee on Citizenship and Immigration (2009) states that "most [immigrants] enter legally and fall out of status while still in Canada." Moreover, Oxman-Martinez et al. (2005) argue that several Canadian immigration policies contain flaws that may cause individuals to fall through the cracks; and thus, become non-status.

People can become non-status immigrants if their inland refugee claims have been rejected by the Immigration and Refugee Board (IRB). In $2004,47 \%$ of 40,408 and in $200641 \%$ of 19,828 refugee claims were rejected (Goldring et al., 2009). In terms of the whereabouts of failed refugee claimants, in May 2008, the Auditor General reported that at least 41,000 of them are subject to an enforceable removal order but Canada Border Services Agency is no longer able to contact or locate them (Auditor General, 2008). In addition, although failed refugee claimants are required to leave the country due to their lack of 
status, under the current system they have a few options to attempt to regain status; however, the process is long and the success rate is low (Showler, 2009).

One of them is the judicial review. Between 1998 and 2008 , only around $13 \%$ of applications to the Federal Court for judicial review were granted and just under half of these reviews overturned the original negative decision (Goldring et al., 2009; Showler, 2009). Moreover, this review process only addresses legal not factual errors, thus, the appeals of some legitimate claimants may be rejected (Showler 2007).

Another option is applying for a Pre-Removal Risk Assessment (PRRA). This process gives failed refugee claimants who have been issued a removal order an opportunity to present new information to demonstrate that deportations would place them at risk (Showler 2007,2009). However, only about $2 \%$ of those applications are accepted (Goldring et al., 2009; Showler, 2009).

Failed refugee claimants can also be stuck in a "limbo" situation with no legal Canadian status, when the government issues a temporary moratorium on removals to their countries of origin because the conditions there are considered too dangerous to send them back (Dolin \& Young, 2004; Khandor et al., 2004). However, the government can decide to have the moratorium lifted at any point, and these in "limbo" people would receive deportation orders again (Khandor et al., 2004).

Rejected refugee claimants can also apply for Humanitarian and Compassionate (H\&C) considerations. Application fees are costly - $\$ 550$ per adult and $\$ 150$ per applicant under 22 years old and the success rate is as low as 2.5 to $5 \%$ (Goldring et al., 2009; Showler, 2009). To make matters worse, the estimated processing time for all these steps from the date of claim submission is four to six years. Therefore, a refused refugee claimant may wait and reside in Canada for this lengthy period of time without a proper legal status; most of them become well settled and have families. This is significant in terms of the following discussion about regularization programs criteria. Several studies point out the shortcomings of the current refugee determination system (Khandor et al., 2004; Showler, 2007, 2009).

In response to the limitations of the current Inland Refugee Protection System, on March 30, 2010, the government of Canada tabled legislation Bill C-11 to reform the refugee determination process 
(Showler, 2010). The Bill, called the Balanced Refugee Reform Act, successfully passed the House of Commons on June 15 and the Senate on June 28,2010 (CIC, 2010a). Currently, it is awaiting Royal Assent to become law (CIC, 2010a). One of the key features of the bill is that the waiting process for the determination hearing has been shortened to 60 days (Showler, 2010). Moreover, the first level decision maker will be a public servant employed by the IRB instead of a Governor-in-Council appointee (Showler, 2010). The most important reform component is the implementation of the Refugee Appeal Division (RAD) of the IRB, which gives claimants the right to a full appeal of the first Refugee Protection Division (RPD) decision on their claim (Showler, 2010). Another proposed feature is the Safe Country of Origin (SCO) list, which denies a claimant from a country on that list to make an appeal to the RAD after receiving a full hearing before the RPD (Showler, 2010). Finally, the reform also aims to speed up the current removal process for rejected claimants. All failed claimants will still be able to apply to the Federal Court for judicial review, but they will not have access to other existing forms of appeals such as the PRRA or the H\&C (Showler, 2010).

Although the Bill has its own limitations, Peter Showler, Director of the Refugee Forum at the University of Ottawa states: "The government has made a practical and legitimate attempt to balance fairness with prompt refugee claim processing" (Showler, 2010, p.1). If this Bill becomes law, there might be room to propose the remediation of systemic flaws as a regularization criterion for those failed refugee claimants under the old system or those who are still waiting to exhaust all available appeal processes to remain. This point will be elaborated further in the following sections.

The Canadian family sponsorship program has also proven to be a pathway to women and children's loss of legal status. This program is highly gendered, because women tend to be over represented in it (Arat-Koc, 1999). For instance, in 2006, 70,506 people were sponsored to come to Canada, but women were nearly twice as often as men to be in a dependent position (Hanley et al., 2006). Sponsored women and children are very vulnerable because of their total dependence on their male sponsors for their immigration papers and economic subsistence (Arat-Koç, 1999). A breakdown in the spousal relationship due to domestic abuse, for example, while the inland application is in process means 
a breakdown in the sponsorship process as well (Arat-Koç, 1999). The consequence of such inland sponsorship breakdown leads to the automatically loss of status of these women. Moreover, if children are born in the country while the application is in process, once the spousal relationship breaks down the woman cannot get legal status based on the citizenship of her Canadian children (LACEV, 2000). Although they may attempt to gain status through $\mathrm{H} \& \mathrm{C}$ application, as mentioned earlier, it is extremely difficult to obtain a positive decision. Clearly, there is a gender-dimension flaw to the family sponsorship program that particularly affects women making them vulnerable to the loss of status.

Similar to the family sponsorship program, the Live-In Caregiver program (LCP) is also highlygendered and has the potential to lead migrant workers to lose their immigration status. One of the program's restrictive requirements is the worker's total dependence on her employer for a minimum period of 2 years; therefore, if she is in an abusive situation, she may be reluctant to complain or quit her job due to fear of jeopardizing her legal status (CLEO, 2009). If she chooses to leave her abusive employer, she has to immediately secure another job in that field, but as discussed later in the paper, this is limited by labour market opinions (LMOs); otherwise, she is left without status and becomes deportable (CLEO, 2009).

The Temporary Foreign Workers Program (TFWP) is also a pathway that often leads to the loss of status. Since the current government took office in 2006, Canada's TFWP has expanded enormously and brought in large groups of cheap and low-skilled labour (Khan, 2009). Alberta, for instance, has increased in the number of TFWs nearly four-fold in five years (Khan, 2009). Workers under this program are mostly seen as a "throw-away workforce" (Khan, 2009, para.6), their temporary job permit is tied to a particular employer which denies them the right to move freely from job to job, or to remain in the country once their contracts have terminated (Khan, 2009). This implies the vulnerability of temporary foreign workers to exploitation and layoffs by their employers. In the case of a worker leaving an abusive employment relationship or being laid off, he/she can stay in Canada until the expiration of his/her work permit or find another job, but it is also extremely difficult to work for a new employer due 
to restrictions under the LMOs; hence, this worker would eventually become a deportable subject. In times of economic downturn and recession, TFWs are highly vulnerable to layoffs.

Indeed, the Canadian government advises employers to dismiss foreign workers before Canadian citizens or permanent residents (Contenta \& Monsebraaten, 2009). Therefore, during the 2009 recession, a news report by the Toronto Star criticized the TFWP as creating an illegal workforce (Contenta \& Monsebraaten, 2009). It provided a few stories of workers who came under this program, but after being laid off they became jobless and often burdened by debt from money paid to recruiters and the need to send remittances for the families' subsistence back home, they have to work in the underground economy (Contenta \& Monsebraaten, 2009). The number of TFWs who were pushed underground is unknown because the government does not have exit control of foreign workers, nor does it keep record of the number of those laid off under the TFWP (Contenta \& Monsebraaten, 2009).

Other situations that lead to migrants having no legal status in Canada are visa overstays. Foreigners may enter Canada legally as workers or students on a temporary basis, and stay in the country after their visas have expired (Standing Committee, 2009). For instance, elderly parents may overstay their visitor visa. As well, foreign spouses, common-law partners, and relatives of Canadian or permanent residents of Canada may come as visitors and stay in the country (Standing Committee, 2009). For some the policy definition of family is too narrow for particular cultures where strong family ties may exist among extended relatives (Robinson, 1983). Due to the lack of proper exit controls in the country, it is almost impossible to know how many overstay their visas (Goldring et al., 2009). There is, however, an estimate that about 8 per cent of those who have visas or 64,000 overstay annually (Jimenez, 2003). Another group of undocumented people are those who enter Canada through human trafficking. In 2004, the RCMP made "a conservative estimate that approximately 600 women and children are trafficked into Canada each year for sexual exploitation alone, and at least 800 for all domestic markets (involvement in drug trade, domestic work, labour for the garment or other industries, etc.)" (Hanley et al., $2006, p .82$ ). Individuals can be trafficked or smuggled through illegal entry, or in many cases through legitimate Canadian immigration programs. The former implies that women are a majority of trafficked 
migrants who are undocumented in the country. In addition, anti-trafficking initiatives developed by the state are strongly criticized as pushing women further into illegal and underground lives (Hanley et al., 2006; Kapur, 2003; Kempadoo, 2005).

In Canada, such anti-trafficking legislation criminalizes and punishes these migrant women, who are often defined as "trafficked victims" (Kempadoo, 2005). Nevertheless, many trafficked women define themselves not as victims but as "migrant workers who have had some bad luck as a result of a bad decision and consider 'rescue' by the state authorities 'capture' —o the state not as savior, but oppressor [sic]" (Kempadoo, 2005, p.41). If they are apprehended, they are often incarcerated or detained, and deported back to their country of origin (Kempadoo, 2005).

Such punitive measures have serious implications for the well-being of women. In some cases, deported trafficked women are often retrafficked or in worse situations, have been executed upon arrival (Kempadoo, 2005). For example, Human Rights Watch has documented the case of the execution of 22 HIV-positive sex workers by the Burmese military after they had been forcibly deported from Thailand (Kempadoo, 2005, p.41). In other cases, stringent anti-trafficking measures have only pushed trafficked women to further invisibility in order to avoid being apprehended and deported (Kapur, 2003). Such invisibility only makes women more vulnerable to situations of violence and abuse by their employers and consumers of trafficked labour (Kapur, 2003). Therefore, recommendations and suggestions have been made to regularize the immigration status of women in such vulnerable circumstances as a measure of protection (Hanley et al., 2006).

Due to the many different situations that lead to migrants having no legal status in Canada, often people do not fit in one rigid category, but several. For example, a temporary foreign worker may loses status for the first time by overstaying his or her visa, and then file a refugee claim that is denied; thus, losing status for the second time (Standing Committee, 2009). Interestingly, even though Canada's estimated non-status population is relatively small compared to the United States, several structural flaws with Canada's immigration policy - the refugee determination system, the family sponsorship program, 
the LCP, the TFWP, the lack of exit controls, and the anti-trafficking legislation - have created more ways that people can fall through the cracks compared to the US.

The living and working conditions of people residing without legal status in Canada is an emerging subject of research and increasingly widely studied by scholars and academics (Lowry \& Nyers, 2003; Nyers, 2005; Santos, 2005; Young, 2005; Berinstein, McDonald, Nyers, Wright \& Zerehi, 2006; Bernhard, Goldring, Young, Berinstein, \& Wilson, 2007; Magalhaes et al., 2010), especially in the area of health and access to health care services (Oxman-Martinez, 2005; Caulford \& Vali, 2006; Simich, 2006; ter Kuile, Rousseau, Munoz, Nadeau \& Ouimet, 2007; Simich, Wu \& Nerad, 2007; Rousseau et al., 2008). Their lack of legal status prevents them from "accessing the services, rights, and protections enjoyed by most people in Canada" (Khandor et al. 2004, p.5). For instance, when non-status immigrants attempt to access a social service, they may face the risk that a government employee - such as a police officer, public housing official, or school principal - will report their status to immigration authorities resulting in deportations (Khandor et al., 2004). Even though in Toronto some public services have adopted a "Don't ask, don't tell" (DADT) policy, it has not been widely implemented and does not always guarantee the safety of undocumented immigrants (Magalhaes et al., 2010). For instance, a recent study by the Toronto Star reveals that "only one in seven Toronto Catholic schools will take in children of illegal migrants, despite an Ontario law that mandates them to accept students regardless of immigration status" (Keung, 2010a, para.1). Furthermore, the Toronto Police has recently revoked its DADT policy (Hanes, 2008). As a result, out of fear, they tend to avoid using some of these services which are often essential for them.

Despite the fact they suffer from having severely limited rights and are denied access to a wide range of service and legal protections, non-status immigrants, like those who have full access, actively contribute to Canadian society. They "work, pay taxes, raise families, and contribute to their communities" (Khandor et al. 2004, p.5). In fact, many of these workers create jobs, pay provincial sales and goods and services taxes, and often contribute to insurance funds, health and union dues and pension plans, through false social insurance numbers (Santos, 2005). They generally take insecure and poorly 
paid jobs that workers with legal status tend to avoid such as construction labourers, in hospitality and manufacturing industries or as domestics working as housekeepers, cooks, cleaners, caregivers, etc. (Soave Strategy Group, 2006).

Although the Standing Committee on Citizenship and Immigration and Government of Canada recently recognized and acknowledged the "regrettable conditions in which many non-status workers and their families live" (2009), they firmly announced that they will "not propose to solve the problem" (2009). They stated that "options for regularizing these non-status workers, while at the same time maintaining program integrity, are limited" (House of Commons, 2009). Instead, they proposed improvements to the Temporary Foreign Workers Program (TFWP) "to stem the growth" of the nonstatus population (Standing Committee, 2009). This also implies the continuous increase in deportations. In fact, a 2009 news article entitled "Deportation surge 50 per cent in a decade" reported this alarming skyrocketing deportation figure in the past ten years in Canada and among those deported, the most affected ones are rejected refugee claimants who are often sent back to their home countries to face persecution and tortures (Cohen, 2009b). There has to be a better way to manage the undocumented population in this country. As discussed below, if the political will is there, regularization can be feasible and can uphold the integrity of the immigration system, while fulfilling humanitarian and compassionate values. 


\section{Chapter 3: Regularization Criteria in Europe and the US}

Several European countries and the US have implemented and proposed regularization programs and mechanisms that are based on a set of economic, social and humanitarian criteria. This section groups and analyzes the criteria that are part of most regularization programs and mechanisms that might be relevant to be considered in the case of Canada. It is important to take into account that these criteria are not stand-alone, but complementary policy measures.

\subsection{National Security and Public Order}

Generally, many states agree that the essential function of regularizations is "to reinstate order amongst their immigrant population by trying to regain control of the situation created by the presence of a large number of illegal immigrants" (Apap, De Bruycker, \& Schmitter, 2000, p.285). As stated by the Parliamentary Assembly of the European Union, these programs can provide information, statistics and control over the demographics of irregular populations (Greenway, 2007). There is a general consensus that an undocumented population living in the shadows "is more likely to escape detection if involved in criminal activities" (Greenway, 2007, p.19). Moreover, if on top of lacking legal status they are also unemployed, it is probable that they may engage in unlawful activities for subsistence (Greenway, 2007). Therefore, accounting for and regularizing these undocumented populations will certainly help support and foster security and provide direction for planning future immigration law. Countries that have implemented regularization programs based on this reasoning include the United States, Italy, Greece, Spain, Portugal and France (Edmonston, Passel, \& Bean, 1990; Fakiolas, 2003; González-Enríquez, 2009; Nascimbene, 2000; Poelemans, \& De Séze, 2000). For instance, the 1981 legalization program in France, for the first time, promoted a dialogue between the state and the clandestine communities, as well as an opportunity to understand the characteristics of its approximately 300,000 undocumented immigrants (Levinson, 2005). The purpose of such an initiative was based on public security and pragmatic grounds: to understand who the non-status immigrants are residing in France and to bring them out of the shadows (Levinson, 2005). Thus, in an attempt to satisfy concerns over public order, the program required the applicants to prove their identity and evidence of a negative criminal record (Greenway, 2007). According 
to a study of regularization programs in Europe, the lack of criminal record has been regarded as an essential and highly ranked requirement for applicants (Kraler, \& Baldwin-Edwards, 2009).

National security as a criterion for immigration reform in the United States was already emerging prior to the 9-11 terrorist attacks, but it became even more compelling and increasingly debated in the legalization discourse since September 11 (Levinson, 2005; Santos, 2005). Although there are different views on the controversial topic of immigration reform, all reform proposals reflected an urgency to address two interrelated national security concerns: to locate and identify all unauthorized immigrants; and to restore order and border enforcement (Papademetriou, 2002). The latter is a mandatory component to prevent the unauthorized entry of aliens in the future. In terms of the former, a consensus exists that in order to address the issue of national security, a better understanding of who is in their midst is an essential step (Papademetriou, 2002). No one can deny that there might be criminals among the undocumented who may in fact have deliberately violated the law causing harm to the country, within the group may also contain individuals who might represent potential threats to the security of the nation (Levinson, 2005). Therefore, several proposals suggest that the best way to reduce criminality and potential terrorist attacks is to register and create a sort of census of all undocumented immigrants. Such an initiative presents an opportunity to investigate or screen registrants against criminal record and national security criteria (Papademetriou, 2002). Those who choose not to register would likely be exposed to stricter enforcement and removal campaigns. Yet, Papademetriou states that registration is not enough and it will be treated as an empty gesture "by the undocumented community and civil society, unless it is accompanied by a reasonable 'earned regularization' initiative" (2002, para.6). An earned regularization is a process of gaining a right to status through a point system by demonstrating their level of integration into the American life and society (Greenway, 2007). This concept will be further explained under the criteria of integration for regularization.

One US regularization proposal was the Fair and Secure Immigration Reform (FSIR), which was introduced by the Bush administration in 2004 (Levinson, 2005). The former US President supported immigration reform by justifying it on the grounds of national security (Levinson, 2005). He stated that 
having a large undocumented population with the possibility of containing a number of undetected criminals and potential terrorists was a threat to the security of the country (Levinson, 2005). FSIR offered undocumented immigrants an opportunity to register and obtain three-year temporary work permits, with a renewal prospect of another three years and a pathway to permanent residency (Levinson, 2005). As a requirement, applicants had to pass national security and criminal background checks (Levinson, 2005). However, this proposal was never implemented due to opposition in the US congress (Levinson, 2005).

\subsection{Economic Consideration}

Another criterion for regularization stems from an economic perspective. Several countries have attempted to deal with the underground economy by attacking its very foundation, the labour of undocumented workers (Santos, 2005). The United States, Greece, Italy, Spain, Portugal and France are among those countries which have implemented regularization programs with an explicit economic goal to regain the ability to regulate the labour market and to collect tax revenue by reducing the size of the underground economy (Levinson, 2005). Moreover, this criterion also has a social justice purpose of safeguarding undocumented workers from vulnerable and abusive working conditions by forcing employers to follow regulations (Greenway, 2007).

The United States implemented an important regularization program in 1986 called the Immigration Reform and Control Act (IRCA). The purpose of the IRCA was to restrict undocumented immigration and reduce the informal economy through employer sanctions and increased immigration enforcement, while regularizing those already living and working without legal status, approximately three million people (Levinson, 2005). This program marked the first time sanctions on employers were used in the US, where employers who knowingly hired unauthorized workers were liable to large fines (Levinson, 2005). Under the IRCA, the congress created another legalization program called the Special Agricultural Worker Act (SAW) which granted temporary residence to undocumented farm and agricultural workers. This Act also provided a pathway for these workers to gradually gain permanent residence status. In order to qualify for such program, agricultural workers had to prove that they were 
paid for a minimum of 90 days of seasonal agricultural work in the US during the previous three years (Levinson, 2005). This program sought to keep a cheap labour force in the agricultural sector.

Recently, regularization legislation similar to the target group of the SAW program, H.R. 371 AgJOBS Act was proposed in 2007. This would have enabled undocumented farm workers and their family members to obtain temporary legal status with an opportunity to apply for permanent residence subject to a number of conditions (Wöger, 2009). To obtain temporary residence, they would have had to prove that they worked at least 863 hours or 150 days during the last two years in the US. Then, to qualify for permanent residence, they would have had to have worked in agriculture for either 100 days per year in each of the five years following enactment or 150 days per year in each of the first three years following enactment (Wöger, 2009). Although such legislation would have improved agricultural job opportunities, benefits, and security for undocumented workers in the US, and helped reinstate control in the agricultural sector, it was not passed by the US congress (H.R. 371, 2007).

The current U.S government under the Obama administration has shown interest in comprehensive reform of the immigration system. Economics is one of the many criteria it uses as supporting argument. Administration officials say that legalization would be balanced with border security and enforcement laws, and they emphasize that a regularization "would not add new workers to the American work force, but that it would recognize millions of illegal immigrants who have already been working here" (Preston, 2008, para.14). In addition, according to independent studies of census data, despite the deep recession in the US, no evidence supports that undocumented workers want to voluntarily return to their country of origin (Preston, 2008). This challenges the belief of those who oppose legalization, who see the recession as a push factor leading underground workers to leave the US. Instead, the number of people working without status in the country and waiting for a formal recognition of their contribution to the American society remains almost the same.

Spain is another country that has implemented programs that are labour market oriented. Its large undocumented workforce was estimated to be around 900,000 people at the beginning of 2005 (Arango, 2009). The Spanish government has implemented seven regularization programs to deal with its 
undocumented population since 1985 . The most recent one took place in 2005 as a response to failures of previous programs to sufficiently manage the country's complex unauthorized migration flows (Arango \& Jachimowicz, 2005). The 2005 program is said to be more successful because it was part of a larger and more comprehensive approach to tackling employment and migration issues (Arango \& Jachimowicz, 2005). In terms of employment, one of the criteria used to determine eligibility for regularization was the possession of a future employment contract for at least six months or three months in agricultural jobs (Arango \& Jachimowicz, 2005). At the same time, the government was committed to the strengthening of immigration enforcement mechanisms such as border enforcement, removals, and workplace inspection (Arango \& Jachimowicz, 2005). Enforcement mechanisms included sanctions against employers who deliberately hire undocumented workers under exploitative and hazardous conditions; directly challenging Spain's informal economy (MigrationWork \& Migrants' Rights Network, 2009). These measures are believed to have contributed to fairer competition in the labour market, increased tax revenues and social security payments and encouraged labour market integration through employment intervention (MigrationWork \& Migrants' Rights Network, 2009). Although there is little evidence to prove that these positive outcomes have been achieved, regularization could be useful in providing data about the sectors where undocumented workers are mainly concentrated and their demographic characteristics. For example, there are several studies (SOPEMI, 1989; Reyneri, 2001; OECD, 2000) which indicate that most regularized workers are young people and many of them are educated (Levinson, 2005).

\subsection{Humanitarian Consideration}

The following criteria are mainly based on humanitarian, human rights and compassionate considerations. Until 1990s, regularizations were mainly implemented as general programs to meet the national security interests of the state or contribute to the economy: to reinstate order and to bring undocumented workers out of the shadows (Kraler, 2009). These continue to be important regularization considerations, but in the last two decades, with an increasing emphasis on human rights and international protection norms together with strong civil society lobbying, the importance of humanitarian criteria has increased (Kraler, 2009). 


\subsubsection{Remediation}

Remediation of systemic flaws in the immigration laws is one of the regularization criteria that can be categorized under the broad label of humanitarian grounds. It usually takes place when governments decide to correct shortcomings of the immigration system, including past and present laws (Apap et al., 2000). In other words, they tend to grant status to those affected by these policy failures and then introduce reforms to the system. The most common policy or systemic failure that European countries such as Belgium, Denmark, Finland, France, Luxembourg, the Netherlands, UK, and Sweden have addressed on the basis of this regularization criterion concerns their asylum system (Apap et al., 2000). A common problem that all these European states shared was that their asylum systems were illequipped to handle the 1990s "asylum crisis" (Kraler, 2009). The collapse of the Soviet Block, the elimination of exit controls in former Communist countries, and war in the former Yugoslavia led to an inflow of persons in need of protection (Kraler, 2009). As a response, countries imposed various restrictions on their asylum system, such as the introduction of the notion of "manifestly unfounded" claims, and the principles of "safe third country" and "safe countries of origin" (Kraler, 2009). This created massive backlogs of asylum applicants and rejected refugee claimants (Kraler, 2009). Due to the accumulation of years of rising numbers of failed asylum seekers, countries have responded with regularization programs and mechanisms on the grounds of humanitarian considerations.

The Belgian government, for instance, pressured by massive public demonstrations especially after an incident where an Nigerian woman died during her deportation, implemented a large-scale regularization program in 2000, mainly to deal with unresolved asylum petitions (Martiniello, 2003). Belgian policymakers were concerned about the slow and lengthy procedures of the asylum application process. Applicants often had to wait for more than two years, sometimes up to seven years for a decision on their cases. On top of that, after the long wait, in most cases they were rejected (Martiniello, 2003). Many of these rejected refugee claimants had largely integrated into the Belgian society; therefore, expulsion was not a realistic option for most of them. Their only alternative was to opt for an underground life and become undocumented (Martiniello, 2003). The 2000 regularization program 
granted status to those with petitions pending who had not received a decision for four years or more and in the case of families with minor children, for three years or more (Martiniello, 2003). The program also targeted those who had lived for at least six years in the country and had been informed of a decision, but had not received any official notification to leave the country during the last five years (Martiniello, 2003). This might be due to the government's decision to issue a moratorium on removals to their countries of origin because the conditions there are considered too dangerous to send them back. Therefore, undocumented individuals from this group also had the opportunity to get their status regularized.

Similarly, in 1991, France pressured by protest movements and hunger strikes, implemented a regularization program for refused long-term asylum seekers who had waited for at least three years for their decision or two years for those who possessed family ties with nationals (Poelemans, \& De Séze, 2000). The average time taken by the French department of refugee protection to process an application was about five years; a period of time that many considered long enough for integration and family establishment (Poelemans, \& De Séze, 2000). Moreover, before the implementation of this regularization program, the government of France introduced a reform of the asylum system aimed to accelerate the decision process (Sohler, 2009). In order to clean the backlog, this reform increased the number of refused asylum seekers. Therefore, the 1991 regularization program was designed "to compensate or attenuate to some extent the effects of previous law reforms" (Sohler, 2009, p.7). It is also important to note that a majority of these rejected refugee claimants were not deported due to violent and insecure situations in their home countries or personal risks (Sohler, 2009).

The regularization criterion of remediation of systemic flaws also applies to other legislative changes and shifts in immigration policies.

In France, the introduction of Pasqua laws in 1993, which presented stricter family reunion conditions and excluded any regularization possibilities within the country for migrants having arrived and stayed without authorization (as family members), led to the creation of a large group of undocumented people (Sohler, 2009). Many of them entered the country before the introduction of the 
1993 laws and attempted to apply for permanent residence status under the inland family reunion class. However, because of changes in the immigration system they remained undocumented. For example, before 1993, foreign parents of children born in France were legally allowed to reside in the country, but the introduction of the Pasqua law imposed restrictions on this right and many of them ended up without legal status (Poelemans, \& De Séze, 2000). Therefore, in 1997, the government implemented a regularization program called the Debré law to regularize the status of parents of French children, spouses of French nationals, young adults who arrived before the age of ten, and those present in the country in an undocumented situation for more than fifteen years (Poelemans, \& De Séze, 2000).

The United Kingdom implemented a regularization program for domestic workers from July 1998 to October 1999. Prior to July 1998, domestic workers were vulnerable to the loss of immigration status if they ran away from abuse and exploitation by their employers. Under the former domestic workers program, their working permits imposed restrictive conditions on them, for instance, they were employertied meaning they were not permitted to leave their original employer for another (Lenoel, 2009). In response to concerns about the treatment of foreign domestic workers, the UK government introduced changes to the Overseas Domestic Workers Concession; the most significant one was the abolition of the employer-tied condition. As a result, a domestic worker enjoys the freedom and right to change employer (Lenoel, 2009). In order to compensate and remediate those who had lost their legal status before the introduction of the reform, the government decided to regularize their stay with a twelve month's leave granted in the first instance, and a possibility of an extension (Lenoel, 2009).

\subsubsection{Family Ties}

The fact of having family ties is also a central reason and criterion for regularizing non-status immigrants in Europe. This type of regularization is often implemented on the basis of humanitarian and compassionate grounds, but particularly taking into consideration the interests of minor children. In Europe, the family ties criterion can cover the following three situations: that of a whole family which lacks legal status; that of a person who has joined a family member who is a legal resident; or that of a person who is the parent of children born in the residing country (Apap et al., 2000). 
In the first situation, where the whole family lacks legal status, countries like Belgium, France, and the United Kingdom have regularized the status of the family members as a form of protection. This is especially advantageous for families with children because the interests of minors are taken into consideration, particularly when they are of school age (Apap et al., 2000).

The most recent and best example that illustrates this situation is the French regularization program implemented in 2006. One of the important events leading to this kind of regularization was the pressure that mobilizations and movements organized by the Réseau Education Sans Frontières (RESF) put on the government to suspend deportation of children of school age (Sohler, 2009). As a response, the Minister of the Interior published a circular in October 2005, suspending further removals of children attending school and their undocumented families until the end of the school year (Sohler, 2009). But as the end of the school year and the deportation moratorium approached, mobilization activities intensified. The government was concerned to avoid a broader regularization program; hence, the program introduced in June 2006 was limited to a narrow target group and was accompanied by several conditions or criteria (Sohler, 2009). The target group included families with children enrolled in school and residing in France since birth or childhood (before the age of 13); furthermore, it imposed the criterion of at least two years presence of one parent in the country, and school (or kindergarten) registration of at least one child since or before September 2005 (Sohler, 2009).

In the case of Belgium, the requirements for regularization eligibility under the first situation of family ties are: five years for families with minors and six years for non-child families (Apap et al., 2000). The UK even requires the proof of longer terms of residence: seven years for families with children and ten years for families with no child (Apap et al., 2000).

In the second situation, undocumented immigrants are often granted status by claiming the presence of family members who are residing legally within the host country, either as citizens or permanent residents (González-Enriquez, 2009). In Spain, this situation is referred to as proving "rootedness" (González-Enriquez, 2009, p.148). In 1994, the Spanish government introduced a special legalization program on the grounds of family reunification. The program covered all undocumented 
immigrants with family members legally residing in Spain (Papadopoulou, 2005). Similarly, and as mentioned above, France implemented the Debré law for regularizing families, under which spouses of French nationals or foreigners in a regularized situation are qualified to apply (Poelemans, \& De Séze, 2000). The condition is that they had to prove at least one year of marriage before 24 July 1997 (Poelemans, \& De Séze, 2000).

In Belgium, there is a permanent regularization mechanism available based on this criterion according to the former article 9.3 of the Aliens Law of 1980 or the recently replaced article 9 bis and 9ter of a legislated reform of the provisions on humanitarian stay in 2006 (Kraler, Bonjour, \& Dzhengozova, 2009). The law specifies that undocumented immigrants qualify for case-by-case regularization on the basis of family ties, which is considered as a form of "long term social attachment," if they are economically dependent aged parents supported by one of their legally resident children; or if they are living in a long-standing relationship to a Belgian citizen or permanent resident, which familial unit would cease if they are removed from the country due to lack of status (Kraler et al., 2009).

Finally, the third situation consists of parents whose children were born in the country where they lack formal immigration status. In France, the Debré law regularized parents of children born in that country (Poelemans, \& De Séze, 2000). Under this law, French national children must be born before 26 June 1997 and at the time of application they should be under the age of 16 years old to be taken into consideration (Poelemans, \& De Séze, 2000). Parent applicants also benefitted as the primary providers for the child by the reduction of the length of residence criterion from 15 years to 5 years (Poelemans, \& De Séze, 20000). Similarly, parents of children with Belgian nationality are also qualified for regularization application according to the Aliens.Law (Kraler et al., 2009).

\subsubsection{Length of Residence}

One of the most frequently used criterion for regularizing non-status people is length of residency. This criterion is also referred as "Fait accompli," which legalizes those who have been without a status in the country since a particular date and/or over a particular period (Apap et al., 2000). Moreover, a program based on this requirement can be permanent or one-off (Apap et al., 2000). The 
former takes into consideration the length of residence in the territory and is implemented on an ongoing basis (Apap et al., 2000). In the United Kingdom, for example, no large-scale regularization has taken place, but instead a case-by-case decision is based on what is called a "long residence concession" (Greenway, 2007, p.15). This system provides indefinite residence permits to those undocumented people who have been in the country continuously for more than 14 years; 7 years for families with children (Greenway, 2007). Another example of permanent regularization is France. On May 11, 1998, the French government established a program that provides permanent residence to undocumented foreigners without family dependants who have been living within its borders for 10 years; 15 years for students; and 3 years for families with children (Poelemans, \& De Séze, 2000).

In addition, a European study on practices in the area of regularization has proposed the automatic acquisition of status of long-term residence for minors with five years' residence in the territory (Kraler et al., 2009). It argues that in most countries, children upon reaching the age of 18 are classed as undocumented immigrants if they are unable to gain a residence permit through some sort of regularization program or humanitarian and compassionate considerations (Kraler et al., 2009). As a consequence, this often results in a whole class of "created illegal immigrant" (Kraler et al., 2009, p.121). To make matters worse, the residence of those children who are either unaccompanied or with their nonstatus parents is often disregarded by states. Therefore, many of them, often long-term residents, are deported to their parents' home country without having ever lived there. The study's proposal to regularize minors is supported by Art. 2(1) of the UN Convention on the Rights of the Child, which "forbids discrimination against any child on the basis of his/her parents' status, including illegal status" (Kraler et al., 2009, p.121). It also argues that the criterion of length of residence should be interpreted generously - registration of birth and some limited evidence of residence or school registration - instead of hard evidence of continuous residence (Kraler et al., 2009).

On the other hand, a one-off program regularizes a finite number of people and requires that their applications are turned in within a specific period of time (Apap et al., 2000). This requirement is designed to "avoid encouraging influx of migrants in response to the announcement of regularization" 
(Papdemetriou, 2005, p.6). For instance, the United States' Immigration Reform and Control Act (IRCA), passed in 1986, legalized undocumented immigrants who could prove continuous residency in the country since January 1, 1982 (Edmonston et al., 1990). Applicants had to apply to the Immigration and Naturalization Service between May 5, 1987 and May 4, 1988 (Edmonston et al., 1990). The Special Agricultural Worker (SAW) program in the U.S, under IRCA, also regularized undocumented agricultural workers who had been living and working in the country for the previous 3 years (Edmonston et al., 1990). In order to get status, they had to register for the program between June 1, 1987 and November 30 , 1988 (Edmonston et al., 1990). The most recent example is Spain's 2005 program; all applicants had to prove they were residents in the country since or before August 8, 2004 (Papdemetriou, 2005).

\subsubsection{Integration}

The previously examined length of residency criterion is very important because it often implies the settlement and integration of these migrants. As Robinson argues, the integrity of a country's immigration system can be "hampered due to the large population of totally established and integrated residents who are without legal status" (1983, p.50). The Parliamentary Assembly of Europe also recommends in its draft resolutions "earned regularization" on the basis of one's integration into the host society. This is a new innovative regularization idea which suggests that people can earn a right to status through a point system by demonstrating their contribution to society through learning the local language and customs, paying taxes, participating in the labour force, contributing to community life and other steps leading towards a process of integration in to the country's social fabric (Greenway, 2007). On the one hand, the benefit to such a program is that "it has the potential to be self-selecting, since only those migrants who were truly motivated to stay would earn enough points, while those who were not would be forced to return home" (Greenway, 2007, p.25). Another advantage of this model is that it eliminates the need for large-scale regularizations and it is flexible it can adapt and respond to local labour market and demographic needs (Papdemetriou, 2005). This has received the most attention in the United States, but has also entered the policy lexicon in the United Kingdom (Papdemetriou, 2005). On the other hand, Papadopoulou (2005) argues that this type of regularization is problematic because it makes legal status a 
reward for those who meet the requirements instead of a right to reside and work in a country legally. Moreover, she argues that a "credits-system would favour the most skilled and well-connected migrants, with little chances for low-skilled" (Papadopoulou, 2005). The latter tend to have fewer contacts to the host population, less time for volunteerism and other community events due to work, and less educational opportunities; hence, it is more challenging for them to learn new languages. Low-skilled undocumented workers should then be regularized under the economic criterion; whereas others, without a proof of employment, could apply for the criterion of integration.

Nevertheless, the earned regularization point system is only a proposal, it has not been implemented. But the criterion of integration has been in place in most European regularizations, for example, in Spain, Portugal, France and the United Kingdom (Apap et al., 2000). Similar to the concept of earned regularization, the integration of the applicant into the host society is taken into consideration as a factor of assessment. Some integration factors include: education of children in the host society, mastering of the local language, employment, contacts with nationals, participation in the armed forces, attendance at cultural and sporting events, etc. (Apap et al., 2000). This is illustrated in Portugal's 1996 regularization program, applicants had to prove involvement in professional activities, a basic ability to speak Portuguese, ownership of housing, etc. (Levinson, 2005). Another example is France's 2006 regularization program, which is designed to target a narrow group of "families with strong ties and integration in France" (Sohler, 2009, p.20). The families' level of integration was evaluated based on the exclusiveness of ties with France (Sohler, 2009). For instance, children must prove absence of ties with the country where they were born and parents must demonstrate effective contribution to and support of their child's education (Sohler, 2009). Moreover, families are evaluated on French language competence, the school performance of children, a clean criminal record, among others factors under the "real will of integration" criterion (Sohler, 2009, p.20).

In the US, a recent proposal for regularization called the Development, Relief, and Education for Alien Minors (DREAM) Act seeks to provide a path to regularization for undocumented youth and youth adults who are able to meet the integration criterion (Batalova, \& McHugh, 2010). The Act is targeted to 
those under the age of 35 and have arrived in the US before the age of 16 . With regards to the integration requirement to be eligible for six years temporary status, they must have lived in the country continuously for at least the last five years, and have obtained a US high school diploma or equivalent (Batalova, \& McHugh, 2010). To be eligible for permanent status, during the six-year period of temporary status, they have to strive to successfully complete at least two years of post-secondary education or military service (Batalova, \& McHugh, 2010). This proposal has been scrutinized by recent studies which estimated that only 38 per cent of the undocumented youth would be able to obtain permanent legal status, while as many as 62 per cent would likely fail to do so (Batalova, \& McHugh, 2010). This implies that while integration criteria and conditions are effective to prove the good will of immigrants to stay and contribute to the host society, stringent criteria can turn out to be exclusionary for many who may be integrating in other ways as well, such as volunteerism.

\subsubsection{Victims of Human Trafficking}

Regularization programs are increasingly implemented as a humanitarian option and means to protect the rights of particularly vulnerable groups, including children and elderly, victims of war and persecutions, and victims of trafficking/forced prostitution (Kraler, \& Baldwin-Edwards, 2009).

Regularizing the status of victims of human trafficking is a widely used criterion in proposals and policy in countries such as: Italy, Belgium, UK, Hungary, Austria, Ireland, Poland, Portugal, Spain, Slovenia, and the US (Kraler, \& Baldwin-Edwards, 2009).

In Italy, for instance, victims of human trafficking and of forced prostitution are granted a special residence permit for reasons of social protection (Ruspini, 2009). This is carried out in compliance with the Single Act in article 18 of the 1998 immigration law (Ruspini, 2009). The Italian government has this permanent regularization mechanism in place to rescue victims of trafficking from the violence of criminal organizations and to assist them through social-integration programs to settle in Italy (Ruspini, 2009). It is important to note the central role played by NGOs in the lobbying and drafting of these provisions (Ruspini, 2009). 
In Portugal, a regularization mechanism has been proposed to grant status to victims of human trafficking who entered the country unlawfully. However, those who suggested such provision also highlighted the importance of imposing a condition: collaboration with the authorities to track down traffickers and criminal organizations (Dzhengozova, 2009).

A more recent regularization mechanism which includes this criterion has been introduced by the Slovakian Ministry of the Interior in the 2002 Act on Stay of Aliens (Reichel, 2009). The Act states that a tolerated stay is issued to an undocumented foreigner, if he/she is a "victim of a criminal offence related to the trafficking in human beings and he/she is at least 18 years old" (Reichel, 2009, p.129). However, the residence permit is only issued for a period of no more than 180 days with a possibility of renewal (Reichel, 2009).

Lastly, the US Department of Health and Human Services (HHS) and the city of Los Angeles in 2005 launched a nationwide public awareness campaign to combat human trafficking (Norris, 2005). This initiative aimed to build awareness on the issue of human trafficking and the methods available to rescue and restore victims. More than 90 organizations have joined the Los Angeles coalition and their staff be trained to help identify and assist victims of trafficking (Norris, 2005). The most important part of this campaign was its regularization component. Once victims are identified, they are directed to the local Los Angeles HHS office, which can certify them as trafficking victims enabling them to "apply for a T-Visa, a special category of visa designed to help victims regularize their immigration status" (Norris, 2005, para.4). While waiting for their applications to be processed, they are also granted access to federal benefits and services (Norris, 2005).

\subsubsection{Medical Condition}

Finally, another reason and criterion for legalization of status is based on humanitarian and compassionate grounds. Medical conditions of the applicant are often considered in regularization programs. In Belgium, Finland, France, Greece, and the United Kingdom, this criterion is explicitly considered on a humanitarian basis (Apap et al., 2000; Poelemans, \& De Séze, 2000). These European states accept people whose illnesses are sufficiently serious, including: people who cannot be transported 
due to health conditions, and those suffering from an illness for which they would be unable to receive treatment in their home country (Apap et al., 2000). While some states are debating the correct meaning of "serious illnesses," France passed new legislation in 1998 which states that "the existence of serious illness is no longer necessary, but only a state of health requiring a medical assumption of responsibility, the absence of which could entail exceptionally grave consequences for the person concerned" (Poelemans, \& De Séze, 2000, p.324). Furthermore, this regularization criterion is often evaluated on a case-by-case basis, and the type of medical conditions and access to medical care in the applicant's country of origin are closely assessed (Reichel, 2009).

Furthermore, the person accompanying the sick person is often allowed to settle temporarily in the host country, but must return to his country of origin once the patient is cured or dead (Apap et al., 2000). In the case of France, temporary status is granted to "the patient's spouse, if they are living together, and to the parents, if he or she is actually responsible for the maintenance of the child" (Poelemans, \& De Séze, 2000, p.323). 


\section{Chapter 4: Regularization: The Case of Canada}

\section{Past and Present Regularizations in Canada}

Before discussing possible regularization criteria that Canada may adopt, it is important to include a retrospective examination of all regularization programs in Canada. First, it demonstrates that the problem of non-status people is not a new phenomenon. Governments in the past have dealt with the same issue. Second, it shows that the government of Canada has proposed and implemented laws and programs that gave non-status migrants a chance to become legal permanent residents.

The first regularization program in Canada was the Chinese Adjustment Statement Program, which took place in 1960 to 1972 . It allowed 12,000 Chinese, who had entered the country illegally before July 1, 1960, to have their status adjusted (Con, Con, Johnson, Wickberg, \& Willmott, 1982). The events leading up to this regularization decision by the government was that until the late 1950 s, Canadian immigration laws worked to the disadvantage of Chinese people who tried to immigrate to Canada $(\mathrm{Li}, 1988)$. The discriminatory nature of the laws made it almost impossible for Chinese-Canadian residents to reunite with family members; therefore, many had to come pretending to be someone else by changing names and belonging to a complex "paper family" (Kelly \& Trebilcock, 2000; Li, 1988). These immigrants were known as the "paper sons" (Con et al., 1982). Con et al. (1982) argue that Canada's previous exclusionary immigration legislation provoked many to come through the back door. Therefore, the Chinese Adjustment Statement Program was introduced partially as the government's remediation of past flaws in the immigration system.

Applicants to the program had to prove "good moral character" and not be systematically involved in illegal immigration (Con et al., 1982; Hawkins, 1988). The then Minister of Citizenship and Immigration, Ellen Fairclough, said very explicitly that it is not the intention of the government to "prosecute or deport from the country any Chinese presently in Canada who have not themselves engaged in assisting other Chinese, apart from their own relatives, to enter Canada illegally" (Hawkins, 1988, p.132). 
In order to balance and uphold the integrity of the Canadian system while showing compassion for these immigrants, first the government remediated past systemic flaws that had negative effects on these Chinese families through a regularization program. Second, it announced that the aim of the adjustment program was to "curtail the illegal entry of Chinese while at the same time legitimizing the status of those already in Canada illegally" (Kelly \& Trebilcock, 2000, p. 331). The measures it took to control illegal entry were to target the clandestine immigration "industry", such as having the RCMP conduct investigations in the Chinese communities (Con et al., 1982). However, these investigations led to human rights violations; which prompted many leaders of the Chinese community to pressure the government to end them (Hawkins, 1988). The success of this adjustment program can also be partially attributed to the mobilization and advocacy work done by a group of Chinese-Canadian leaders (Con et al., 1982).

Around the same period, the government also passed immigration laws that would regularize inland visitors with temporary status and undocumented immigration status. Section 34 of the 1967 immigration laws, for example, allowed visitors to apply for permanent resident status from within Canada (Khandor et al., 2004). Another law, the Immigration Appeal Board Act was passed in the same. year enabled anyone living in the country without legal immigration status, who had received a deportation order to appeal this order (Khandor et al., 2004). Although the decision of the Immigration Appeal Board was final, many people got a positive response based on humanitarian and compassionate grounds. These two laws were in effect until 1972, when the government repealed Section 34 and 1973 when it changed powers of the Immigration Appeal Board because of the difficulty in managing the large number of applications (Khandor et al., 2004).

As a consequence of these changes to immigration laws, many individuals found themselves stuck between the old and new system, the majority with no legal status. The Minister of the Department of Manpower and Immigration, Mr. Robert Andras, publicly recognized the need to remediate the shortcomings of former laws which had created huge backlogs of applications and removal orders appeals, by stating that "decency demands that it be done fairly" (Hawkins, 1989, p.48). Therefore, the 
1973 Adjustment of Status Program was implemented to bring a solution to the gaps created by systemic flaws in the immigration laws. It granted status to about 39,000 people from over 150 countries (Hawkins, 1989). Moreover, compared to the previous regularizations, decisions were based on a set of more thoughtful application criteria such as: "length of residence in Canada, family relationships, financial stability, and employment records, as well as compelling grounds for compassionate consideration" (Hawkins, 1989, p.48). However, the program was in effect for a short period of time, people had to apply within 60 days which created a sense of urgency (Hawkins, 1989).

Another adjustment of status initiative took place from 1983 to 1985 (Khandor et al., 2004). This regularization was based on a report about non-status immigrants in Canada produced by the Minister's Review Committee, called Illegal Migrants in Canada (Robinson, 1983, 1984). In 1982, the Minister Lloyd Axworthy asked his Canada Employment and Immigration Advisory Council to study the situation of undocumented immigrants in the country to identify them (Hawkins, 1989). However, the report the Council produced was unhelpful, because it was based on inadequate research and expertise (Hawkins, 1989). Therefore, the Minister asked W.G. Robinson, a well-known Vancouver lawyer, to prepare the Illegal Migrants in Canada report (Hawkins, 1989). The report stated that there were many wellintegrated, long-term undocumented people residing in the country (Robinson, 1984). It provided several recommendations, including a rejection of general amnesties. However, it proposed the "Case-by-Case" discretion landing of long-term undocumented residents as a permanent feature of Canada's immigration system (Robinson, 1983, 1984). The government accepted this recommendation but on a one-time rather than permanent basis (Hawkins, 1989). The outcome was the announcement of the Minister's Review Committee program, whose criteria for regularization requires that an applicant has five years or more of residence in Canada, be successfully established and integrated, and not have a criminal record (Hawkins, 1989; Khandor et al., 2004). Other factors considered in applications were employment, work skills, family ties or having children in Canada, conditions in the applicant's home country, and the circumstances leading to their lack of status (Robinson, 1983; Hawkins, 1989). People could choose to apply in person or anonymously through another party (1989). 
According to Robinson, the integrity of the immigration system is maintained through the regularization of these long-term immigrants because: "the integrity of our country is also diminished through the long-term build-up of a population of totally established and integrated residents who are without legal status" (Robinson, 1983, p.50). Moreover, the one-time basis feature of the program, instead of a permanent one also helped the government to uphold the value of integrity. Furthermore, rigid laws were introduced in the following years after the Minister's Review Committee program for regularization of status. For example, in 1984, the government modified its visa-exempt list by adding a visa requirement for Guyana, Jamaica, Peru, and Guatemala (Hawkins, 1989).

On 21 May 1986, the government introduced another regularization program which was known as a "partial amnesty" for refugee claimants. The event leading up to this special regularization was the passage of Bill C-55, which added an oral hearing as an assurance of procedural fairness in the refugee status determination process. Under this legislation, all refugee claim applicants had an opportunity to present their claims in oral hearings. However, this change escalated the existing backlog, contributing to delays in processing as long as forty months (Kelly \& Trebilcock, 2000). To be fair to these applicants who had been waiting for such an extended period of time and who had settled themselves and their families, this backlog needed to be cleared. Therefore, the government decided to implement a partial amnesty and give "landed status to those refugee claimants who are likely to establish themselves successfully in Canada" (Kelly \& Trebilcock, 2000,p.414). Out of the 28,000 applications, $85 \%$ were successful. The flip side of this was an influx of Portuguese and Turkish refugee claimants coming in hope of future regularization programs (Kelly \& Trebilcock, 2000). However, the government took immediate action to protect the integrity of the system by removing both Portugal and Turkey from its visa-exempt list (Kelly \& Trebilcock, 2000). As a result, the flow of claimants from these countries effectively stopped.

Another regularization program, the Deferred Removal Orders Class (DROC), was implemented 1994 to 1998 . The program provided status to about 3,000 mostly Chinese people, although some were from Iran and other countries (Khandor et al., 2004). Prior to the DROC, the Canadian government 
decided to issue moratoriums on removals of rejected refugees whose countries of origin were considered too dangerous to send them back (Kelly \& Trebilcock, 2000). Many of these failed refugees were stuck in "limbo"; they stayed with no legal status for many years, establishing themselves and building families in Canada (Guang, \& Lu, 1996). In 1994, the government lifted the moratorium exposing more than 5,000 rejected Chinese refugee claimants to deportation orders (Kelly \& Trebilcock, 2000). Because of this, Chinese-Canadian community groups such as the Mainland Chinese Refugee Organization (MCRO) began to put pressure on the government to stop deportation practices (Guang, \& Lu, 1996). Their mobilization activities and efforts led to the DROC regularization program (Guang, \& Lu, 1996). In order to qualify for the program, applicants had to prove that their refugee claims had been refused and they had received a deportation order three years before the announcement of this program. They also had to demonstrate that they had paid income taxes for over half a year and did not have a criminal record (Kelly \& Trebilcock, 2000). However, about half of all undocumented Chinese people did not get status under DROC because they did not meet the residency requirement and/or they had serious health conditions, such as kidney disease (Khandor et al., 2004).

Although the government acted fairly by granting legal status to these "in limbo" residents, there were some restrictive application requirements and criteria that excluded many from qualifying. For instance, those who are seriously ill were excluded from this program, although many of them got sick in Canada while living without status (Guang \& Lu, 1996).

Two other regularization programs that were special in character were introduced in 1981 for Haitians and 2002 for Algerians residing in Quebec (Khandor et al., 2004). In the case of the Haitians, many people became undocumented when they overstayed their student and work permits (Khandor et al., 2004). Due to the worsening political situation in Haiti, these people residing in Quebec got together to demand status collectively, instead of having each one to apply for refugee status on a case-by-case basis (Khandor et al., 2004). Successful mobilization, especially by the Office of Christian Haitians, created widespread public awareness and media coverage (Khandor et al., 2004). The regularization was eventually extended to include temporary foreign workers and student visa-holders (Khandor et al., 2004). 
Nevertheless, like previous programs, this one also excluded immigrants with criminal records and serious health conditions; for instance, one applicant was rejected because of tuberculosis (2004). Under this program, more than 4,000 people were regularized (2004).

For the Algerians, the 2002 regularization was similar to the DROC in that it was designed for failed refugee claimants living 'in limbo' (Wright, 2003). The government issued a moratorium on their removals in 1997 because of ongoing violent conflicts in Algeria (Lowry, \& Nyers, 2003). However, four years later after signing an important trade deal with Algeria, the Canadian government decided to resume the deportation of Algerians (Wright, 2003). In light of the deportation threat, many non-status Algerians in Quebec came together to form the group Action Committee for Non-status Algerians (CASSA) (Lowry, \& Nyers, 2003). Their mobilization also was very successful, leading to the 2002 Special Regularization Procedure for Algerians Residing in Quebec (Wright, 2003). The criteria for applying were residence in Quebec, not having left the country at any time since 2002, and evidence of integration into Canadian society (Khandor et al., 2004).

Finally, the only option currently available for undocumented people in Canada to get their status legalized is through application for Humanitarian and Compassionate $(\mathrm{H} \& \mathrm{C})$ considerations. The $\mathrm{H} \& \mathrm{C}$ consideration is a permanent regularization mechanism which allows anyone living without legal status in Canada to apply. Yet, as mentioned earlier, the scope, efficiency and effectiveness of this program has been very questionable due to its expensive application fees $(\$ 550$ per adult and $\$ 150$ per applicant under 22 years old), long processing delays (applicants routinely wait 2 to 3 or more years for a response), highly discretionary decision-making (difficult for an applicant to know about their case status or what information to submit in order to receive a positive $\mathrm{H \& C}$ decision), and in particular its low success rate (2.5 to 5 per cent) (Canadian Council for Refugees, 2006; Goldring et al., 2009).

Furthermore, although applications are evaluated based on regularization criteria examined above, the ambiguity of these criteria and discretionary decision-making deny the right of many wellintegrated, self-supporting, and bona fide individuals with compelling cases to obtain legal status. According to the $\mathrm{H} \& \mathrm{C}$ consideration guide, each individual case is assessed based on country of origin, 
risks of persecution or torture, level of establishment in Canada, employment and financial situation, family ties, the interests of minor children, criminal records, medical conditions, and others (Khandor et al., 2004; CIC, 2009a). Nevertheless, an analysis of negative H\&C application decisions released by the Canadian Council for Refugees (CCR) shows the arbitrariness and ambiguity of the criteria "establishment in Canada" and "significant duration" (2006b).

For example, in one case, the immigration officer disregarded as sufficient the integration of an applicant, who had four years' residence in Canada, was employed (the employer wrote a letter praising the applicant as a good employee) and had significant athletic involvement (the applicant successfully participated in track teams in important competitions) (CCR, 2006b). In another case, an applicant's employment contribution was not taken into consideration because he was working in an unskilled job in Canada, despite having been a medical doctor in his home country (CCR, 2006b). Ironically, it was his lack of legal status that forced him to work at unskilled jobs; thus, the applicant was penalized for the problems caused by his lack of status (CCR, 2006b). In another instance the applicant had a compelling "length of residence" claim (had been in Canada for 13 years), was a moratorium country national living in limbo, had a clean criminal record and was not subject to any other inadmissibility under the Act, such as security or health; however, he received a negative $\mathrm{H} \& \mathrm{C}$ application decision (CCR, 2006b). This last case again shows the discretionary interpretation of the regularization criteria.

Therefore, there are many evidential facts that illustrate the limits and shortcomings of the application for $\mathrm{H} \& \mathrm{C}$ consideration. Rather than having this type of discretionary and restrictive case-bycase regularization mechanism which keeps a high failure record, Canada should consider a more comprehensive immigration reform along with regularization programs based on compelling criteria that would help uphold the integrity, as well as the humanitarian and compassionate values of Canada. 


\section{Chapter 5: Criteria for Regularization in Canada Compared to the EU and the US}

Throughout the examination of past and present regularization programs and mechanisms implemented in Canada, a set of regularization criteria was briefly discussed that could serve as a basis of comparison with and an analysis of those implemented or/and proposed by the US and some of the EU members. Among the criteria used in regularization programs in Canada, the ones that have been selected and will be further elaborated in this section are consistent with those analyzed in chapter 3 . In addition, the scope of the current situation of the undocumented immigrants in the Canadian context will also be incorporated in the following discussion.

\subsection{National Security and Public Order}

With respect to Canada, the only time that the government has taken the initiative to explicitly research, produce a report about the findings and attempt to deal with the situation of non-status immigrants living within its borders was in 1982, when the Minister for Employment and Immigration, Lloyd Axworthy decided "to undertake a study of illegal immigrants in Canada, analyze the origins and extent of the problem, and provide him with suggestions..." (Robinson, 1984, p.475). As mentioned earlier, the purpose of the study was to support public order in the country by establishing a better understanding of the characteristics of those who are living in the shadows. As a result, one of the main criteria for regularization under the Minister's Review Committee program (1983-1985) was the possession of "no major criminal record" and the submission of documentation that indicate how the applicants became non-status (Khandor et al., 2004).

Similar to regularization programs in the EU and US, almost all regularization programs in Canada have imposed the requirement of a clean criminal record on their applicants in order to fulfill the public order criterion. The central criterion of the Chinese Adjustment Statement Program was proof of the applicants" "good moral character" and that he/she was not involved in illegal immigration (Khandor et al., 2004). Similarly, the special regularization program for Haitians residing in Quebec required applicants to have valid identification documents and successfully pass a security and criminal check. Other programs that asked for security and criminal checks included DROC, the special regularization 
procedure for Algerians residing in Quebec, and today's H\&C Applications. Therefore, similar to regularizations in Europe and US, not having a criminal record is regarded as a principal and highly essential criterion to qualify for regularization.

In terms of the criterion of national security, Canada reacted promptly to the event of September 11, 2001. The Canadian government implemented an anti-terrorism plan, which included the AntiTerrorist Act Bill C-36. In the Act, immigration was portrayed as a national security priority. The government specified a five-part security strategy: accelerating the permanent resident biometric card for newcomers; more security screening of refugee claimants; augmenting detention capacity; increasing deportation activity; and hiring 100 new border enforcement officers (Parliament of Canada, 2001; Solidarity Across Borders, n.d.). Unlike the US, where the legalization discourse became more compelling after the 911 terrorist attacks, Bill C-36 did not mention the possibility of regularization of the existing undocumented population. Instead, the security strategy plan laid out in the Anti-Terrorist Act has only led to rising and blatant human rights violations and racial profiling (Solidarity Across Borders, n.d.).

In a globalized world, Canada like other North American and European countries is not immune to terrorist attacks. Imposing laws that restrict and strengthen border enforcement to block undocumented immigrants is not sufficient to protect national security. It is also important to restore order by locating and identifying all unauthorized individuals living within its borders. Canada should consider what other countries, such the US, have been proposing to first register and create a census of all undocumented immigrants residing in the country, along with a regularization program to grant them legal status. Then, stricter enforcement and removal campaigns could be developed to expose those who deliberately choose not to register or attempt to get regularized in order to commit criminal and terrorist acts. This group of people represents potential security risks to public order and threatens the safety of the nation.

As previously discussed, in 2009, the Standing Committee on Citizenship and Immigration issued a report about the situation of temporary foreign workers and non-status workers. The positive side of this initiative is that at least the government has made an effort to acknowledge and recognize the findings of 
scholars, labour unions, immigrant rights organizations, and media reports about the situation of the existing non-status population in Canada. Pertaining to the public order criterion, the Standing Committee on Citizenship and Immigration indicates that periodically the media reports about cases where undocumented individuals repeatedly commit crimes and yet avoid deportation (Standing Committee, 2009). In fact, this information is consistent with the argument by the Parliament Assembly of the European Union that undocumented people involved in criminal activities are harder to identify and more likely to escape and circumvent detection (Greenway, 2007). Despite recognizing and understanding these facts, the Canadian government refuses to do anything or propose any solution to the problem of the hundreds of thousands of people living in the shadows, some of whom may or may not threaten the country's public safety and national security.

\subsection{Economic Consideration}

In the case of Canada, no regularization initiative has explicitly targeted the underground economy. Nevertheless, like regularization programs implemented by US and Spain, all applicants were required to show proof of employment. For instance, the Adjustment of Status Program in 1973 asked applicants to present employment records and show economic stability (Hawkins, 1989). Moreover, the special regularization program for Haitians in Quebec indicated in its list of criteria that job skills and employment records increase the success rate of those applying (Khandor et al., 2004). Another example is the DROC, which gave priority to people who worked for at least 6 months in Canada (Khandor et al., 2004).

Currently, it is estimated by the Greater Toronto Home Builders' Association and a construction union Local 183, that there are about 10,000 to 20,000 undocumented construction workers in Toronto alone (Jimenez, 2003). Among the many low skilled jobs these workers perform include: installing drywall, carpentry, house framing, and painting (Jimenez, 2003). In a report for the Portuguese Canadian National Congress in 2005, Santos (2005, p.11) argues that "were it not for undocumented workers it is difficult to imagine how our construction industry would have been able to function over the past decade. The current system penalizes both undocumented workers, and their employers" by deporting the workers 
and creating labour shortages in the sector. In addition, the Ontario Construction Secretariat in a report concluded that the annual revenue loss to governments in its sector from unpaid taxes and premiums surpassed $\$ 1.5$ billion (The Globe and Mail, 2006). In turn, unscrupulous contractors were profiting from the 50 per cent or more savings on labour costs by referring to their undocumented employees as independent contractors (The Globe and Mail, 2006). Yet, as mentioned earlier, there are also those undocumented workers who use false social insurance numbers to pay provincial sales and goods and services taxes, and contribute to insurance funds, health and union dues and pension plans, but can never access such services themselves (Santos, 2005). In light of this, there were a number of proposals similar to the US proposal of H.R. 371 AgJOBS Act. One of them by former Immigration Minister Denis Coderre proposed to regularizing those gainfully employed to continue in their employment by granting them renewable temporary work permits that would eventually lead to permanent residence (Jimenez; 2003; Santos, 2005). It was also argued that this regularization would benefit the Canadian labour market and economy by addressing the labour shortages in sectors such as the Niagara farm region, construction trades, etc. (Santos, 2005).

The 2009 Standing Committee on Citizenship and Immigration report raised several issues with respect to the vulnerable situations of undocumented workers. For instance, there is a general acknowledgement of the "stories of the untold thousands who find jobs under the table and quietly toil for years, often at jobs Canadians refuse" (Standing Committee, 2009). The report also pointed to those nonstatus workers who had no option but to tolerate substandard working conditions due to their fear of being reported by their employers to the immigration authorities (Standing Committee, 2009). Ironically, despite recognizing that these workers address labour market needs, and their vulnerability to exploitation and economic downturns, the Canadian government disregarded any possible option for regularizing their immigration status (House of Commons, 2009).

Although the Canadian government has taken an important step by acknowledging the situation of the undocumented workers, it is also essential to find solutions for the problem. After examining the economic criterion for regularization in EU and US, there are four significant lessons for Canada. First, a 
labour market-oriented regularization program could help the state to reinstate order in the labour sector and gain revenue by collecting taxes. Second, like the case of Spain, such program could provide data about the labour sectors where undocumented workers are mainly concentrated and their demographic characteristics. Third, it could also contribute to upholding the human rights of undocumented workers, by safeguarding them from abusive employers who constantly take advantage of them by threatening deportation. Lastly, granting these workers legal status is a way to value and compensate their work and contribution to the Canadian economy and society.

\subsection{Remediation}

The criterion of remediation analyzed in the cases of European countries also applies to the Canadian context. An example of this type of regularization is the 1973 Adjustment of Status Program. This program was similar to France's Debré law, which was implemented after the introduction of the 1993 Pasqua laws, a set of laws that restricted any future possibility for permanent residence application through the previously in place inland family reunification. The French government wanted to remediate the situation of those who got stuck between the old system and the 1993 Pasqua laws by providing them with an opportunity to apply for status. Likewise, Canada's 1973 Adjustment of Status Program corrected flaws created when Sec 34 of the 1967 Immigration Regulations (permitted inland visitors to apply for permanent residence) and the Immigration Appeal Board Act (permitted non-status immigrants to appeal their deportation order) were revoked (Hawkins, 1989). The program regularized those individuals who had fallen through the cracks and had no means to get status when these immigration law reforms took place (Hawkins, 1989). Therefore, both in the French and Canadian cases, regularization programs were implemented after the replacement of a generous immigration law with a more stringent one as a form of remediation and compensation for the problems created by these changes.

Another case of regularization under the same criterion also involves changes and shifts in immigration policies, but this time towards a more just and humanitarian direction. The most outstanding example in Canada is the Chinese Adjustment Statement Program (1960-1972). The program was implemented to remediate and compensate for the discriminatory family reunion laws prior to the late 
1950s (Li, 1988). Due to former discriminatory family reunification provisions of immigration law, many people entered and stayed in the country illegally as they were unable to formally apply for family reunification (Con et al., 1982),

As explained earlier, the regularization program for domestic workers implemented in the United Kingdom also falls under the category of remediation introduced after fairer and more humanitarian changes in immigration laws. To recall, the UK government abolished the employer-tied condition formerly stated in the Overseas Domestic Workers Concession. This change aimed to protect domestic workers from losing their immigration status as a result of layoffs or escaping from abusive employers. Prior to the amendments, these workers were unable to switch employers which exposed them to a higher risk of exploitation and abuse. After these changes, the government decided to regularize the status of those domestic workers, who having left their contract-tied employers due to layoff or security and safety reasons, became undocumented.

Several lessons applicable for Canada could be extracted from this UK example. Even though domestic workers under the Canadian Live-in Caregivers program are more advantaged when compared to the ones in UK, because the former has a pathway to permanent residence after working for two years in the country, they are still in a vulnerable position when they encounter abusive employers. If they are laid off or decide to leave their employer, they have to find another job in the same field quickly; otherwise, they will lose their status or any possibility for permanent residence. Nevertheless, it is not easy to find a new employer. Both employers and LCs are constrained by the government's labour market opinions (LMOs) to hire or work. A LMO assesses what impact hiring a foreign worker would have on Canada's labour market. Employers who want to hire foreign workers have to apply for LMOs, but not all LMOs are approved (Contenta \& Monsebraaten, 2009). Therefore, most of the LCs would choose to maintain employer-tied relationships for at least two years fearing that they would lose status or the chance to apply for permanent residence. This increases their vulnerability to maltreatment and exploitations in the workplace. The government should address this issue by introducing stricter enforcement laws to oversea the contract-based employment relationship under the LCP. More 
involvement by the government to protect the rights of LCs will prevent workers from being exploited by their employers. And even if they end up losing their job, the government should assist them with finding and matching them with a new employer. Therefore, more oversight will help reduce the chances of LCs from unnecessarily losing status. If such amendment or enforcement succeeds to be implemented, a regularization program should be given to grant status to those who lost status in the former system.

The LCP is a special program under the Temporary Foreign Workers Program; however, unlike the LCP, the rest of the TFWP does not provide a direct pathway to permanent residence. Nevertheless, there are also relevant lessons from the UK example to the TFWP. As to the situation in the UK, prior to the amendments in the Overseas Domestic Workers Concession, the current employer-tied condition under the TFWP has also led and will continue to lead to the loss of status of many foreign workers. The program is widely criticized for being poorly monitored and leaving TFWs vulnerable to exploitation (Contenta \& Monsebraaten, 2009). Similar to the LCs, although TFWs have the right to switch employers or jobs, it is extremely difficult to successfully do so. Workers also have to first find another employer willing to hire them, then they have to get approval from the federal government, more specifically, the employer has to apply for a LMO and get it approved.

When the economy is doing well, TFWs can easily renew work permits with the same employer or get federal approval to switch employers or jobs; however, in economic downturns when domestic unemployment rises, the number of jobs formerly approved with LMOs may be curtailed. If the latter happens, employers who want to renew work permits for those TFWs already on their payroll will be unable to do so; therefore, they are forced to lay them off instead. Many proposals have been made to demand reform of the TFWP that address systemic problems (Contenta \& Monsebraaten, 2009; Khan, 2009; Nakashe \& Kinoshita; 2009). Some experts say if these shortcomings are not properly dealt with, the TFWP will end up following the path of the failed guest worker programs in Europe, which resulted in generations of marginalized and resentful residents (Contenta \& Monsebraaten, 2009). These arguments became even more compelling during the 2008-2009 economic recession when large numbers of TFWs were laid off due to massive cuts in the number of jobs previously approved with LMOs, many 
of whom chose to become undocumented workers (Contenta \& Monsebraaten, 2009; Khan, 2009; Nakashe \& Kinoshita; 2009).

It is essential that Canada takes into consideration the changes suggested in these proposals and the case of the UK. This is especially urgent in light of the intensification of the trend and increase in numbers of temporary foreign workers in Canada. Since 2003, the TFWP has almost doubled to fill labour shortages identified by employers and the Canadian government (Contenta \& Monsebraaten, 2009). On top of supporting amendments and more specifically changing the restrictive employer-tied condition to the current LCP and TFWP, a regularization path such the one implemented in UK for those temporary foreign workers who became undocumented prior to the introduction of the new policy changes is recommended. Currently, skilled TFWs can apply for permanent residence under the Canadian Experience Class, but its success rate is still unclear because it is a relatively new program (implemented in 2008) (CIC, 2010b). However, low skilled TFWs are not eligible for the Canadian Experience Class program. Therefore, Canada could learn from the UK example, by first granting them a twelve month's residence and work permit, and then provide them with an option for an extension based on demand in their particular labour sector. By doing so, the systemic flaws or gaps created by the current TFWP would be remediated and those who fall through these systemic gaps would be protected.

A similar kind of regularization criterion could be applied to the case of the family sponsorship program in Canada. The government should introduce changes to address the gender-dimension flaw and gap in the family sponsorship program in Canada. As identified in a previous chapter, many people, particularly women, suffers from a loss of legal immigration status due to a breakdown of the spousal relationship while the inland application is in process. Moreover, many of these women, often victims of domestic abuse, turn to homeless shelters for help after running away from their sponsors. Yet, these shelters have not been proven to be completely safe places or sanctuaries for non-status individuals. A recent news report by the Toronto Star entitled "Homeless shelters should be safe sanctuary, activists say" scrutinized the increasing number of incidents where removal enforcement officials raided these shelters or waited outside of these buildings to apprehend undocumented clients (Keung, 2010b). Shelter workers 
are worried that incidents such as the February 27 raid at Beatrice House (a downtown shelter for women and children) "would scare non-status women in need from seeking help in order to avoid potential arrests and deportation" (Keung, 2010b, para.2). For humanitarian reasons, the Canadian Council for Refugees calls for the regularization of status of those dependants, mostly women and children, who have left their sponsors due to physical or/and psychological abuse (2006). Although under the current system, they can apply for $\mathrm{H} \& \mathrm{C}$ considerations; they are often unable to afford the expensive application fees and the success rate of the program is very low.

The fact that many European countries have applied regularization programs based on the criterion of remediation of systemic flaws in their asylum program, it is appropriate to analyze whether this could be applied to the current Canadian inland refugee determination system. Countries that have implemented regularization programs for failed asylum seekers did so due to delays in the determination system; some of them like France have done so after introducing reforms that address the gaps of that system. Although Canada's refugee determination system does not have the exact same flaws, there were several problems identified in chapter 2 . The main shortcoming is the absence of a full appeal process in the Refugee Protection Division (RPD). Currently, failed refugee claimants who want to appeal their first RPD decision on their claim have to apply for outside appeal processes: Judicial Review, Pre-Removal Risk Assessment (PRRA), and Humanitarian and Compassionate applications. The estimated wait time for the first RPD decision and exhaustion of all appeal processes is about four to six years. In other words, a rejected refugee claimant would wait for a long time to receive their case and appeal decisions, while they integrate and settle themselves and their families in Canada.

In 2010 the Conservative government introduced the Balanced Refugee Act or Bill C-11 to reform the inland refugee protection system. This Bill has successfully passed the House of Commons, but is currently awaiting for Royal assent. Some important changes in Bill C-11 are: the acceleration of the waiting process for the determination hearing by shortening it to 60 days; less discretion by the first level decision maker by replacing Governor-in-Council appointee with public servants employed by IRB; the acceleration of the removal process for rejected claimants by offering them assistance through 
financial compensation; and the implementation of the Refugee Appeal Division (RAD). The latter will replace appeals made to the PRRA and the $\mathrm{H} \& \mathrm{C}$, which will help reduce backlogs in these systems and speed up the voluntary return of failed claimants to their home country. If the Balanced Refugee Act indeed becomes law, it will strengthen the argument for a regularization program for those rejected refugee claimants who became undocumented before the implementation of such law or reform on the ground of remediation of systemic shortcomings and flaws of the former RPD system. Moreover, it should also apply to those who find themselves trapped with delays during the implementation process of such reforms. Indeed, as reviewed in section 4.1, a similar kind of regularization, the "partial amnesty" for refugee claimants, was implemented in Canada in 1986 due to backlogs and delays created by reforms (introduction of oral hearings) at that time.

One final group that should be granted formal immigration status are those failed refugee claimants who had no option of return and have remained in the country for a significant period of time and can show evidence of integration and settlement in Canada. Individuals who belong to this group include those from countries subject to moratoriums on removals due to violent and insecure situations. Currently, countries that are subject to suspension of removals are Afghanistan, the Democratic Republic of Congo, Haiti, Iraq and Zimbabwe (CCR, 2006b). However, moratoriums on three other countries formerly on the list were lifted in 2009 due to potential improvements in public order. These countries include Burundi, Liberia and Rwanda (CIC, 2009b). Even though the government acknowledges that many of these countries' nationals have been in Canada for a decade or more and may have developed significant ties to this country $(\mathrm{CIC}, 2009 \mathrm{~b})$, the success rate of those applying for $\mathrm{H} \& \mathrm{C}$ is extremely low (CCR, 2006b). As reviewed above, Canada had implemented regularization programs for this particular group of undocumented people before in 1981 and 2002. Belgium and France are also two of the countries that have regularized people affected by moratoriums on removals.

\subsection{Family Ties}

In Canada, the family ties criterion, stated as having "family relationships" (Hawkins, 1989) was applied as a criterion in the 1973 adjustment program. It was also used as a criterion for regularization by 
the Minister's Review Committee, which specified the requirement of having family ties or children in the country. Currently, the only way to apply for regularization using this criterion is through $\mathrm{H} \& \mathrm{C}$ consideration; however, the program's delay and low success rate suggests that it is very ineffective and restrictive. In the meanwhile, many families with no legal status or with mixed status (some members with legal residence and others who lack immigration status) have been forcefully separated by deportation orders in Canada (Cohen, 2009b).

The government should respond to this issue immediately because it directly undermines the integrity of the immigration system. As argued by Robinson in the report for the Minister's Review Committee in 1983, "the issue is not merely one of compassion, although the alleviation of misery and fear is obviously desirable. The integrity of our immigration system is also adversely affected where anomalies are created" (p.50). He illustrated this with an example saying that it does not make any sense that a Canadian-born child should be separated from his or her non-status family or the whole family deported, but later on the child might return to Canada at the age of eighteen and sponsor the immigration of the family (Robinson, 1983). In fact, in 2009 a news report featured the story of an undocumented single mother and her grade 2 Canadian-born daughter who were going to be deported back to South Korea (Taylor, 2010). Kim Suk Yeung, the undocumented mother, expressed her frustration at being deported, yet, she is hopeful that her child, Eugene, might be able to return to Canada at age 18 and then sponsor her (Taylor, 2010).

After living and working in Canada for more than eight years, Kim was worried that she and her child will not be able to adapt life back in her homeland (Taylor, 2010). In particular, she was worried that her child was being deported to a country she has never been to, and since she attended school here her education will be interrupted (Taylor, 2010). The latter is especially worrisome because Eugene was doing very well at school. For instance, she was given the school's citizenship award to recognize her leadership skills (Taylor, 2010). Their story touched many people in their community who initiated a campaign pleading to let them remain in the country. The campaign's central focus was on the rights of Eugene, a Canadian-born child (Taylor, 2010). According to a 1999 Supreme Court of Canada ruling in 
the case of Mavis Baker and her four children, the rights of the Canadian-born children were recognized and thus should get "substantial weight" (Taylor, 2010). However, post-9/11 anti-terrorist enforcements have eroded children's rights (Taylor, 2010). The Baker decision was a very important decision and a milestone in protecting the rights and interests of children. The government should seriously consider the family ties criterion on the basis of child protection, and humanitarian and compassionate grounds, as practiced in other countries like Belgium, France, and the UK.

Prioritizing the interests of minor children is a compelling reason to implement a regularization program for undocumented parents of Canadian-born children and families with minors where all members lack legal status. In a proposal for the regularization of individuals and families without status, the Canadian Council for Refugees (CCR) demanded Canada to "comply fully with its obligations under the Convention on the Rights of the Child by giving primary consideration to the best interests of the child and ensuring that families are not separated" (2006a, para.5).

Furthermore, CCR also proposed for the regularization of individuals with family members who have refugee or permanent status in Canada (2006a). As examined in section 3.3.2, this request for regularization is similar to Spain's 2005 program which granted status to all undocumented immigrants with family members legally residing in its territory (Papadopoulou, 2005). Other countries that have used comparable regularization criterion were France and Belgium. The former regularized spouses of French nationals or foreigners in a legal situation, and the latter granted status to those economically dependent aged parents on their legally resident children and those undocumented persons living in a long-standing relationship with a Belgian citizen or permanent resident.

\subsection{Length of Residence}

Unlike Europe, where permanent regularization mechanisms based on long-term residence criterion have been implemented in several countries such as France (10 years for single adults, 15 years for students, and 3 years for families with children) and UK (14 years for single adults and 7 years for families with children), in Canada, all previous regularization programs fall under the one-off criteria. For example, in the cases of the Deferred Removal Orders Class (DROC) in 1994 to 1998 and the special 
regularization for Algerians in 2002, the government granted status to many failed refugee claimants who were stuck in limbo and stayed for many years because the government had previously issued them moratoriums due to the dangerous conditions of their home countries (Khandor et al., 2004). Another example is the Chinese Adjustment Statement Program, which allowed 12,000 Chinese who had entered the country before July 1, 1960 to have their status adjusted (Con et al., 1982). This program lasted from 1960 to 1972 (Con et al., 1982). The 1973 regularization, the Adjustment of Status Program, also included the length of residence in Canada as the application criterion. However, the program was held within a shorter period of time, people have to apply within 60 days which created a sense of urgency (Hawkins, 1989).

One other Canadian example is the Minister's Review Committee program, which criterion for regularization of 5 years or more of residence targeted explicitly to a group of non-status people, who Robinson (1984, p.479) described as "lived in Canada for long periods of time and exhibited all of the positive characteristics of Canadian citizens and permanent residents." It is important to recall that one of the recommendations made by Robinson for the Minister's Review Committee was the implementation of a permanent case-by-case mechanism for the landing of long-term undocumented residents (Robinson, 1983, 1984). Moreover, in his paper Fundamental (In)Justice: The Deportation of Lon-term Residents from Canada, Cohen argues from human rights and entitlement perspective that Canada's international obligation under the International Covenant on Civil and Political Rights (ICCPR) and national obligation under the Charter of Rights and Freedoms oblige the government to regularize the status to long-term residents in the country (1994). He believes that deportation of these long-term and well-integrated residents is a violation of section 7 of the Canadian Charter, which states that: "Everyone has the right to life, liberty and security of the person and the right not to be deprived thereof except in accordance with the principles of fundamental justice" (Cohen, 1994, p.460). This is well illustrated in the cases of longterm undocumented residents who have rooted in Canada through their families, employment, and communities, and have little or no connection to their countries of nationality (Cohen, 1994). In those cases, Cohen argues that deportation will violate the liberty and security of the person (1994). Both 
arguments and recommendations by Robinson and Cohen are parallel to the existing permanent regularization mechanisms that a number of European countries have solely on the basis of long-term residence.

Furthermore, as proposed in Europe, Canada should also consider providing automatic regularization of status to minors who are long-term residents in its territory. Indeed, Canadian research on this issue reveals that a considerable number of youth (unaccompanied or separated) age out of care when they reach 18 year-old without a citizenship or permanent resident status; therefore, many of them become vulnerable to exploitation and deportation (Hare, 2007). Like the case of many European countries, the majority of young people from this group have lived and grown up in the host country without having ever gone back or been to their parents' homeland (Hare, 2007). Therefore, it is a violation to their rights and entitlement if they are to be expelled or deported to a place without having ever lived there or have no attachment to.

Although Canada's H\&C consideration takes into account the criterion of length of residence, decisions are not evaluated solely on this criterion but also on several other conditions that restrict undocumented individuals who have resided in the country for a significant duration of time to qualify for permanent residence. Therefore, the government of Canada should consider such recommendations to establish a permanent pathway for undocumented people to get their status regularized on the basis of length of residence.

\subsection{Integration}

The statement by Robinson quoted in the above section indicates the direct connection between length of residence and the criterion of integration and settlement. The longer someone stays in a country, the more integrated he or she is. Furthermore, to reiterate, Robinson (1983) emphasized in his report that the integrity of Canada's immigration system can be "hampered due to the large population of totally established and integrated residents who are without legal status" (p.50). Indeed, many of the recent regularization proposals in the United States, and draft resolutions in the Parliamentary and Assembly of 
Europe advise the implementation of the criterion of integration (Greenway, 2007). Moreover, countries that have applied such criterion include Spain, Portugal, France and the United Kingdom.

In the Canadian context, previous regularizations such as the 1981 Special Regularization Program for Haitians residing in Quebec stated that knowledge of French language, job skills, and employment are assets in successful applications (Khandor et al., 2004). The successfully established and integrated criterion was also a requirement in the Minister's Review Committee (Robinson, 1983); however it is very uncertain how an applicant's settlement in the country is judged to be as "successful". For example, the 2002 Special Regularization Procedure for Algerians residing in Quebec also required applicants to prove evidence of integration into Canadian and Quebec society (Khandor et al., 2004). However, there was no indication of how this criterion of integration was evaluated. In contrast, the application for $\mathrm{H} \& \mathrm{C}$ consideration does indicate what accounts for the integration of applicants into Canadian society and it is reviewed on the basis of financial stability, volunteer work in their community, having studied or upgraded their skills, and possessing English or French language skills (Khandor et al., 2004). Although this program has components which evaluate the criterion of integration like the "earned regularization" proposal in Europe and US, the low success rate of $\mathrm{H} \& \mathrm{C}$ applications raises questions as to the priority and importance given to this criterion by immigration officials.

Therefore, in order to make the evaluation process of such criterion more transparent and less discretionary, it is necessary to introduce a program similar to the "earned regularization" proposal, which gives applicants a right to status through a point system that evaluates each of the components of their contribution to society. Furthermore, a proposal for regularization by the Canadian Council for Refugees strongly recommended that integration should not be viewed from a narrow economic perspective but emphasized instead social, cultural and familial integration (2006a). In other words, the employment requirement in 1981 Special Regularization Program for Haitians residing in Quebec should have been mainly evaluated as part of the economic criterion, while the criterion of integration should have focused more on other aspects of settlement. This is particular important considering that in the current application for $\mathrm{H} \& \mathrm{C}$ considerations has turned down cases that have demonstrated strong social, cultural and familial 
integration, but CIC rejected the applicants for "having made little effort to adapt to life in Canada" due to, for instance, in one case, the temporary unemployment of one of the parent after experiencing a serious car accident as illustrated in the case of Rakeb Al Rekabi (he and his family had lived in Canada for 11 years) (CCR, n.d.).

\subsection{Victims of Human Trafficking}

While several countries in Europe and the US have pathways of regularization for victims of human trafficking, Canada has no regularization option available for this group of individuals. Although there are relatively fewer victims of trafficking in Canada compared to other industrial countries, it is important to recall that in 2004 the RCMP estimated that 1400 trafficked women and children lived in Canada (Hanley et al., 2006). These victims of trafficking are often punished by the Canadian government instead of being rescued or protected. Current anti-trafficking legislation criminalizes and punishes these people through apprehension, incarceration and detention, and deportation (Kempadoo, 2005). Under humanitarian and compassionate grounds, Canada should seriously consider the implementation of a regularization and protection program for all victims of trafficking. CCR also suggested the regularization of status for "survivors of trafficking" in their 2006 proposal (2006a). Moreover, Hanley et al. argue that these migrants are the "deserving undocumented" (2006, p.99). They are "deserving" in the sense that they should get protection from exploitation by granting them legal status (Hanley et al., 2006). It is essential that Canada follow the example set by the US Department of Health and Human Services (HHS) and the city of Los Angeles, who have developed an initiative to spread awareness and identify the victims of trafficking, and give them an opportunity to apply for immigration status. While their applications are in process, they are also granted assistance and access to federal benefits and services (Norris, 2005).

\subsection{Medical Condition}

Finally, another common reason and criterion for regularization of status in humanitarian and compassionate grounds is based on the medical condition of the applicant. It is important to recall that most regularization programs in Canada have excluded those with serious medical problems because they 
put an "excessive demand" on health care services (Khandor et al., 2004). For instance, the DROC program (1994-1998) restricted applicants who were seriously ill, such as those with physical disabilities or have chronic diseases - kidney disease, HIV/AIDS, leukemia, etc. Several people thought this is vey unfair, because undocumented immigrants may have gotten sick here in Canada, often due to the unsafe and dangerous work conditions that they are forced to accept. Indeed, many of the failed applicants in the DROC program had evidence that they got sick in Canada while living and working without status, yet they were refused on the basis of their medical condition (Guang \& Lu, 1996).

Under the current system, the application for $\mathrm{H} \& \mathrm{C}$ consideration might take medical hardship as a regularization criterion. Like in Belgium, France, Greece, and the United Kingdom, the H\&C application in Canada takes into consideration cases where a person's illness is deemed as "serious" whose medical condition prevents him/her from flying or whose medical condition cannot be adequately treated in the country of origin (CIC, 2009a). Nevertheless, unlike these very stringently set conditions which are often hard to document or prove, France took a few important humanitarian and compassionate milestones in this regard. First, as discussed earlier, the French legislation recognizes that a person should be treated within the country and granted temporary status just by the fact of having a health condition that requires a medical assumption of responsibility (Poelemans, \& De Séze, 2000). In other words, the delay or absence of such treatment could aggravate or lead to exceptionally grave consequences for the person concerned (Poelemans, \& De Séze, 2000). Another humanitarian consideration that Canada could learn from France is the provision of temporary status to the person accompanying or the ultimate caregiver of the sick person such as the spouse or the parent(s).

Furthermore, although the application for $\mathrm{H} \& \mathrm{C}$ consideration in Canada sets out a list of conditions for assessment, there are some inconsistencies with regards to the eligibility for this medical condition criterion in the legislative level. For instance, the Pre-removal Risk Assessment (PRA) legislation provides that "the risk of life must not be caused by the inability of the country of return to provide adequate heath [sic] or medical care" (CIC, 2009a, p.39). Contrary to the general provision in the $\mathrm{H} \& \mathrm{C}$ application, the PRA legislation specifies that considerations are only given to those who can prove 
that they are prevented from accessing medical treatment due to persecutory or discriminatory reasons (CIC, 2009a). Therefore, Canada should clarify the eligibility conditions for qualifying this regularization criterion in a consistent manner. In addition, more humanitarian and compassionate considerations should be incorporated in the decision-making process, such as the developments taking place in France. This is particularly essential, given the low success rate and discretionary decision-making process of the H\&C applications. Furthermore, a more comprehensive regularization program has been proposed by the Canadian Council for Refugees. It advocates that status should be given to "persons whose removal from Canada would involve a serious rights violation (e.g. persons with a serious medical condition for which treatment is available in Canada but not in the country to which they would be removed)" (2006a). 


\section{Chapter 6: Conclusion}

Undoubtedly, the issue of undocumented residents is very complex. At first glance, an application for Humanitarian and Compassionate $(\mathrm{H \& C})$ consideration is the only regularization option currently available in Canada that incorporates at least six of the criteria analyzed above (national security and public order, economic, family ties, length of residence, integration, and medical condition). But H\&C consideration is recognized as ineffective and restrictive due to its expensive application fee, long processing time, strict and discretionary decision-making and very low success rate. The Canadian Council for Refugees has documented a series of stories about individuals whose lives are on hold as a result of limits and shortcomings of $\mathrm{H} \& \mathrm{C}$ consideration (2006b). Many applicants for $\mathrm{H} \& \mathrm{C}$ consideration have compelling cases but they are almost always rejected.

In addition, although the 2009 Standing Committee on Citizenship and Immigration report represents a very important milestone (the Canadian government has moved from ignorance to acknowledgement of the devastating situations in which thousands of non-status people live), the Committee did not propose any policy solution to deal with the problem. The latter is justified by the government because it is concerned about the implications of implementing a regularization program and at the same time maintaining the integrity of the immigration system.

Chapter 2 informs that the majority of the undocumented residents in Canada who entered the country through non-clandestine routes and ended up losing status due to systemic flaws in immigration laws, such as sponsorship programs, temporary work and student visa programs, and the inland refugee determination system. This implies that the government might have information and could conceivably control and identify the undocumented within Canada. Consequently, it is feasible for the government to implement regularization programs for regulatory and humanitarian reasons, and balance this through the enactment of stricter exit controls, enforcement policies regarding the removal of rejected refugee claimants and individuals with expired visas, and the introduction of reforms to remediate systemic flaws in the immigration system. With this in mind, this paper has explored the different regularization criteria applied and proposed in the US and some European countries, as well as past regularization programs 
implemented in Canada. The ultimate purpose is to propose possible regularization criteria and options that Canada could take into consideration as policy solutions for the issue of the undocumented residents.

The first examined criterion is based on national security and public order. This criterion is often justified on the grounds of obtaining a better understanding of who is undocumented in the host country and to bring them out of the shadows. The major requirement for applicants to qualify is proof of no criminal record. The second criterion is economic. Many countries have implemented regularization programs that are labour market-oriented, to regain the ability to regulate the labour market and reduce the size of the underground economy. Programs using this criterion tend to be accompanied by enforcement mechanisms such as issuing sanctions against employers who deliberately hire undocumented workers. A positive implication of this criterion is an attempt to uphold the rights of such workers, who are often laboring in vulnerable and abusive circumstances. To qualify for the program, the applicants are required to prove their ability to work and provide evidence of employment.

Under the category of humanitarian criteria, remediation of systemic flaws in the immigration system prompted many European governments to regularize the status of failed refugee claimants who have waited 2 to 4 years or more for a decision on their asylum applications. Simultaneously, these regularization programs were usually accompanied by reforms to the asylum seeking system aimed at accelerating the decision process. Moreover, rejected refugee claimants who were stuck in limbo for a significant period of time due to a moratorium on removals to their countries of origin also benefited from this regularization criterion. Lastly, the introduction of amendments to the immigration system, such as more stringent policies (France's Pasqua laws restricted family reunion conditions) or protection laws in favor of the immigrants (the elimination of the employer-tied condition in UK's Overseas Domestic ' Workers Concession) also tended to be accompanied by regularization programs.

Another humanitarian criterion pertains to those with family ties in the host country. Regularization programs of this type usually target either undocumented families without legally resident members or individuals who can prove attachment to family members who are legal residents, or parents of children born in the country of residence. Length of residence of the applicants is also taken into 
consideration in most of these regularization programs and mechanisms. This criterion requires evidence of duration of residence in the country or documents indicating the date of entry. Long-term undocumented residents have often benefited from these programs. Another important criterion is to show a significant degree of integration in the host society. This is often evaluated on the basis of language proficiency, contributions through employment and taxes, and participation in community life such as sports, volunteering, school attendance, and other factors that show the applicants' integration in the host country's social fabric. It is crucial to highlight that the interests of minor children are often prioritized in all regularization criteria and proposals on humanitarian grounds.

There are also regularization criteria targeted to members of a particular group of people; for example, victims of trafficking. These were implemented on the basis of human rights and social protection, but also as an incentive to collaborate with the authorities to identify and penalize criminal organizations. Finally, the criterion of a medical condition is used for temporarily or permanently regularizing the status of individuals with serious illnesses who face hardships if transported back to their home country because medical treatment is not available or affordable. It is important to note that France grants temporary status to those who need medical treatment as well as their undocumented caregivers.

Each of these eight regularization criteria has been further analyzed and compared with the case of Canada. It is encouraging to see that the majority of these criteria were either implemented at some point in the past or are part of current Canadian immigration law but they vary in scope and form. For example, even though length of residence was one of the criteria used in most of the regularization programs implemented in this country, there has never been a permanent regularization mechanism based on long-term residence like the one in France. The latter has a continuous regularization pathway in place for families with children who have been living in the country for 3 years, 15 years for students, and 10 years for single adults. Like the case-by-case proposal by Robinson, this paper also recommends that Canada should implement an ongoing regularization program on the basis of public order, social, economic and various humanitarian criteria. Nevertheless, such a proposal is not sufficient without the introduction of a point system similar to the "earned regularization" proposed in Europe and the US. The 
"earned regularization" point system will bring order to the very discretionary and ineffective H\&C consideration process and provide a more effective pathway for regularizing the status of the undocumented immigrants in Canada.

Furthermore, it is recommended that the Canadian government also considers the suggestions made in each subsection under chapter 5 and learn from the regularization criteria other countries have applied in their one-off programs and permanent mechanisms. For instance, one of the lessons is to prioritize the best interests of minor children, in particular those of school age; this might mean a temporary or permanent regularization of their status and their parents or guardians. Another lesson might be the introduction of a regularization program after the introduction of reforms to remediate systemic flaws in immigration laws or after passing stringent laws and legislation that aims to uphold the integrity of the immigration system. This regularization criterion is relevant for individuals who fell out of status and remained in the country due to sponsorship breakdowns, rejected refugee claims, and lay offs or breakdowns in TFWP and LCP employment contracts.

Finally, there are many compelling reasons and foreseeable benefits to implementing regularization programs as a policy solution: they enable the state to reinstate order and regain control over their immigration population for national security and public order purposes, have a positive impact on tax revenues, acknowledge the contribution of the undocumented and integrate workers labouring in the underground economy, remediate and restore gaps in the immigration system, and most importantly, enhance the human rights and human dignity of those in an undocumented situation. 


\section{References}

Apap, J., De Bruycker, P., \& Schmitter, C. (2000). Regularisation of Illegal Aliens in the European Union. Summary Report of a Comparative Study. European Journal of Migration \& Law, 2(3/4), 263-308.

Arango, J. (2009). Spain. In Martin Baldwin-Edwards \& Albert Kraler (Eds), REGINE Regularisations in Europe: Study on practices in the area of regularisation of illegally staying third-country nationals in the Member States of the EU. Appendix A: Country studies (pp. 83-93). Vienna: ICMPD. Retrieved from July 10, 2010, from http://research.icmpd.org/1184.html

Arango, J., \& Jachimowicz, M. (2005). Regularizing immigrants in Spain: A new approach. Migration Information Source. Retrieved from May 10, 2010, from http://www.migrationinformation.org

Arat-Koç, S. (1999). Neo-liberalism, state restructuring and immigration: Changes in Canadian policies in the 1990s, Journal of Canadian Studies, 34(2), 31-56.

Auditor General (2008). 2008 May Report of the Auditor General Office of the Auditor General, Ottawa. Available on-line: www.oag-bvg.gc.ca

Batalova, J., \& McHugh, M. (2010, July). DREAM vs. reality: An analysis of potential DREAM Act beneficiaries. Migration Policy Institute. Retrieved June 18, 2010, from: www.migrationpolicy.org/pubs/DREAM-Insight-July2010.pdf

Berinstein, C., McDonald, J., Nyers, P., Wright, C., \& Zerehi, S. (2006). Access not fear: Non-status immigrants \& city services. Joint Centre of Excellence for Research on Immigration and Settlement (CERIS).

Bernhard, J. K., Goldring, L., Young, J., Berinstein, C., \& Wilson, B. (2007). Living with precarious legal status in Canada: Implications for the well-being of children and families.Refuge, 24(2), 101-114.

Bernhard, J., \& Young, J. (2009). Gaining institutional permission: Researching precarious legal status in Canada. Journal of Academic Ethics, 7(3), 175-191.

Canadian Council for Refugees (CCR) (n.d.) Lives on hold: The faces behind Humanitarian and Compassionate Applications. Retrieved June 22, 2010, from: http://www.ccrweb.ca/profiles.pdf

Canadian Council for Refugees (CCR) (2006a, June). Proposal for the regularization of individuals and families without status. Retrieved June 20, 2010, from: http://www.ccrweb.ca/regularization.html

Canadian Council for Refugees (CCR) (2006b, September 6). Lives on hold-The limits of H\&C. Retrieved June 12, 2010, from: http://www.ccrweb.ca/LivesonholdH\&C.pdf

Caulford, P., \& Vali, Y. (2006). Providing health care to medically uninsured immigrants and refugees. Canadian Medical Association Journal, 174(9), 1253-1254.

Citizenship and Immigration Canada (2008). True or False? If you are an undocumented worker in Canada, you are an illegal immigrant. Retrieved February 2, 2010, from:

http://www.cic.gc.ca/english/department/media/facts/workers.asp 
Citizenship and Immigration Canada (2009a). Immigrant applications in Canada made on Humanitarian or Compassionate grounds. Retrieved from April 3, 2010, from

http://www.cic.gc.ca/english/resources/manuals/ip/ip05-eng.pdf

Citizenship and Immigration Canada (2009b, December 24). Measures for people affected by the lifting of the temporary suspension of removals to Burundi, Liberia and Rwanda. Retrieved from July 14, 2010, from http:/www.cic.gc.ca/english/department/media/notices/notice-suspension.asp

Citizenship and Immigration Canada (2010a, June 29). Balanced Refugee Reform passes final hurdle in the Senate, launches summer tour to promote refugee resettlement. News Release. Available online at: http://www.cic.gc.ca/english/department/media/releases/2010/2010-06-29a.asp

Citizenship and Immigration Canada (2010b, June 26). Canadian Experience Class. Available online at: http://www.cic.gc.ca/english/immigrate/cec/index.asp

Cohen, M. (2009a). Undocumented women: Pushed from poverty and conflict, pulled into unjust disparity. Journal of Public Health Policy, 30(4), 423-426.

Cohen, R. (1994). Fundamental (in)justice: The deportation of long-term residents from Canada. Osgoode Hall Law Journal, 32(3), 457-501.

Cohen, T. (2009b, October 12). Deportations surge 50 per cent in a decade. Montreal: The Canadian Press.

Community Legal Education Ontario (CLEO) (2009). Immigration and refugee fact sheet: Immigrant women and domestic violence. Toronto, ON: CLEO. Available online at: www.cleo.on.ca

Con, H., Con, R., Johnson, G., Wickberg, E., \& Willmott, W. (1982). From China to Canada: A history of the Chinese communities in Canada (1982). Edgar Wickberg (Ed.). Toronto: McClelland and Stewart in association with the Multiculturalism Directorate, Dept. of the Secretary of State, and the Canadian Government Publishing Centre, Supply and Services Canada.

Contenta, S., \& Monsebraaten, L. (2009, November 1). How we are creating an illegal workforce: Controversial federal program brings in foreigners for temporary jobs, but leaves them ripe for abuse. Toronto Star. Retrieved July 2, 2010, from http://www.thestar.com/news/investigations/article/719355--how-we-re-creating-an-illegalworkforce

Dolin, B., \& Young, M. (2004). Canada's immigration program. Ottawa: Parliamentary Information and Research Service. Retrieved November 17, 2009, from

http://www,parl.gc.ca/information/library/PRBpubs/bp190-e.htm\#removalstxt

Dzhengozova, M. (2009). Portugal. In Martin Baldwin-Edwards \& Albert Kraler (Eds), REGINE Regularisations in Europe: Study on practices in the area of regularisation of illegally staying third-country nationals in the Member States of the EU. Appendix B: Country profiles of $22 E U$ Member States and the USA (pp. 115-122). Vienna: ICMPD. Retrieved July 10, 2010, from http://research.icmpd.org/1184.html

Edmonston, F., Passel, B., \& Bean, J. (1990). Undocumented migration to the United States: IRCA and the experience of the 1980's. Washington, D.C.: The Urban Institute. 
Fakiolas, R. (2003). Regularising undocumented immigrants in Greece: Procedures and effects. Journal of Ethnic \& Migration Studies, 29(3), 535-561.

Goldring, L., Berinstein, C., \& Bernhard, J. (2009). Institutionalizing precarious migratory status in Canada. Citizenship Studies, 13(3), 239-265.

González-Enriquez, C. (2009). Spain, the cheap model: Irregularity and regularisation as immigration management policies. European Journal of Migration \& Low, 11(2), 139-157.

Government of Canada (2009, August). Government of Canada Response to the Seventh Report of the Standing Committee on Citizenship and Immigration: Temporary Foreign Workers and NonStatus Workers. Retrieved November 18, 2009, from http://www2.parl.gc.ca/HousePublications/Publication.aspx?Docld=4017803\&Language=E\&Mo $\mathrm{de}=1 \&$ Parl $=40 \&$ Ses $=2$

Greenway, J. (2007). Report regularisation programmes for irregular migrants. Parliamentary Assembly Council of Europe. Retrieved July 12, 2010, from http://assembly.coe.int

Guang, T., \& Lu, J. (1996). Struggling for legal status: Mainland Chinese mobilization in Canada. Refuge, $15(1), 26-35$.

Hanes, A. (2008, November 21). Immigration policy gets cut by police chief; 'Don't Tell'; Officers can't turn blind eye to suspected violations. National Post, p. A.15. Retrieved September 7, 2010, from Canadian Newsstand Major Dailies.

Hanley, J., Oxman-Martinez, J., Lacroix, M., \& Gal, S. (2006). The "deserving" undocumented?: Government and community response to human trafficking as a labour phenomenon. Labour, Capital \& Society, 39(2), 78-103.

Hare, F. (2007). Transition without status: The experience of youth leaving care without Canadian citizenship. New Directions for Youth Development, 113, 77-88.

Hawkins, F. (1989). Critical years in immigration: Canada and Australia compared. Kingston, Ontario: McGill-Queen's University Press.

Hawkins, F. (1988). Canada and immigration: Public policy and public concern (2nd ed.). Kingston Ont.: McGill-Queen's University Press.

H.R. 371--1 10th Congress: AgJOBS Act of 2007. (2007). In GovTrack, us (database of federal legislation). Retrieved July 10, 2010, from http://www.govtrack.us/congress/bill.xpd?bill=h110371

House of Commons Committees (2009, August). Government of Canada Response to the Report of the Standing Committee on Citizenship and Immigration: Temporary Foreign Workers and NonStatus Workers. Retrieved November 18, 2009, from http://www2.parl.gc.ca/HousePublications/Publication.aspx?Docld=4017803\&Language=E\&Mo $\mathrm{de}=1 \&$ Parl $=40 \&$ Ses $=2$ 
Jimenez, M. (2003, November 15). 200,000 illegal immigrants toiling in Canada's underground economy. The Globe and Mail, A.1.

Kapur, R. (2003). The other side of globalization: The legal regulation of cross-border movements. Canadian Woman Studies, 22(3/4), 6-15.

Kelley, N., \& Trebilcock, M. (2000). The making of the mosaic: A history of Canadian immigration policy. Toronto: University of Toronto Press.

Kempadoo, K. (2005). Victims and agents of crime: The new crusade against trafficking. In Julia Sudbury (Ed.) Global lockdown: Race, gender, and the prison-industrial complex (pp.35-55). New York and London: Routledge.

Keung, N. (2010a, July 14). Few Toronto Catholic schools accept non-status students. The Toronto Star. Retrieved August 2, 2010, from http://www.thestar.com/news/investigations/immigration/article/835923--few-toronto-catholicschools-accept-non-status-students

Keung, N. (2010b, March 8). Homeless shelters should be safe sanctuary, activists say. The Toronto Star. Retrieved June 23, 2010, from

http://www.thestar.com/news/investigations/immigration/article/776527--homeless-sheltersshould-be-safe-sanctuary-activists-say? $b n=1$

Khan, A. (2009). Temporary workers need a permanent solution. Canadian Dimension, 43(6), 37-38.

Khandor, E., Mcdonald, J., Nyers, P. \& Wright, C. (2004). The regularization of non-status immigrants in Canada, 1960-2004: Past policies, current perspectives, active campaigns. Available on-line: http://www.ocasi.org/status/Regularization_booklet.pdf

Kraler, A. (2009). Regularisation: A misguided option or part and parcel of a comprehensive policy response to irregular migration? ICMPD: Australia.

Kraler, A., \& Baldwin-Edwards, M. (eds.) (2009) REGINE. Regularisations in Europe: Study on practices in the area of regularisation of illegally staying third country nationals in the Member States of the EU Country Studies. ICMPD: Austria. Available online at:

$\mathrm{http} / /$ ec.europa.eu/justice_home/doc_centre/immigration/studies/docs/regine_report_january_200 9 _en.pdf

Kraler, A., Bonjour, S., \& Dzhengozova, M. (2009). Belgium. In Martin Baldwin-Edwards \& Albert Kraler (Eds), REGINE Regularisations in Europe: Study on practices in the area of regularisation of illegally staying third-country nationals in the Member States of the EU. Appendix B: Country profiles of 22 EU Member States and the USA (pp. 14-24). Vienna: ICMPD. Retrieved July 10, 2010, from http://research.icmpd.org/1184.html

ter Kuile, S., Rousseau, C., Munoz, M., Nadeau, L., \& Ouimet, M. (2007). The universality of the Canadian health care system in question: Barriers to services for immigrants and refugees. International Journal of Migration, Health and Social Care, 3(1), 15-26. 
Latin American Coalition to End Violence Against Women and Children (LACEV) (2000). No (wo)man's land LACEV, Toronto. Retrieved November 2, 2009, from http://www.mujer.ca/NoWomansLand.pdf

Lenoel, A. (2009). France. In Martin Baldwin-Edwards \& Albert Kraler (Eds), REGINE Regularisations in Europe: Study on practices in the area of regularisation of illegally staying third-country nationals in the Member States of the EU. Appendix A: Country studies (pp. 102-123). Vienna: ICMPD. Retrieved from July 10, 2010, from http://research.icmpd.org/1184.html

Levinson, A (2005). The regularisation of undocumented migrants: Literature, survey and country case studies. University of Oxford: Centre on Migration, Policy and Society (COMPAS). Available online at: www.unityblueprint.org/_documents/research-and-policy/legalization-inothercountries $/ 1 . \% 20$ Amanda $\% 20$ Levinson $\% 20-\% 20$ Centre $\% 20$ on $\% 20$ Migration.pdf

Li, P. (1988). The Chinese in Canada. Toronto: Oxford University Press. Living \& growing in Canada: A Chinese Canadian perspective(1980). In Chu I., Fong C. K., Jew M. s. and Council of Chinese Canadians in Ontario. (Eds.). Toronto: Council of Chinese Canadian in Ontario.

Lowry, M., \& Nyers, P. (2003). "No one is illegal": The fight for refugee and migrant rights in Canada. (roundtable report). Refuge, 21(3), 66-72.

Magalhaes, L., Carrasco, C., \& Gastaldo, D. (2010). Undocumented migrants in Canada: A scope literature review on health, access to services, and working conditions. Journal Immigrant Minority Health, 12, 132-151.

Martiniello, M. (2003). Belgium's immigration policy. International Migration Review, 37(1), 225-232.

MigrationWork \& Migrants' Rights Network (2009). Irregular migrants: The urgent need for a new approach. Author. Retrieved from July 10, 2010, from: http://www.migrantsrights.org.uk

Nascimbene, B. (2000). The regularisation of clandestine immigrants in Italy. European Journal of Migration \& Law, 2(3/4), 337-359.

Norris, J. (2005, September 28). HHS, City of Los Angeles launch campaign to identify, assist victims of human trafficking. U.S. Department of Health and Human Services. Available online at: http:/www.acf.hhs.gov/trafficking/rescue_restore/pres_sept28_2005.htm

Nyers, P. (2005). The regularization of non-status immigrants in Canada: Limits and prospects. Canadian Review of Social Policy,(55), 109-114.

OECD Secretariat (2000). Some lessons from recent regularisation programmemes. In Combating the illegal employment of foreign workers (pp.53-70) [online]. Paris: OECD. www.oecd.org

Oxman-Martinez, J., Hanley, J., Lach, L., Khaniou, N., Weerasinghe, S., \& Agnew, V. (2005). Intersection of Canadian policy parameters affecting women with precarious immigration status: A baseline for understanding barriers to health. Journal of Immigration Health, 7(4), 247-258.

Papademetriou, D G. (2002). A grand bargain: Balancing the national security, economic, and immigration interests of the U.S. and Mexico. Migration Policy Institute. Retrieved July 14, 2010, from www.migrationpolicy.org/files/bargain.pdf 
Papademetriou, D G. (2005a) The "Regularisation" option in managing more effectively: A comparative perspective. Migration Policy Institute, Policy Brief No. 4

www.migrationpolicy.org/pubs/PolicyBrief_No4_Sept05.pdf

Papadopoulou, A. (2005, May). Regularization programmes: An effective instrument of migration policy? Global Migration Perspectives, No.33. Global Commission on International Migration. Retrieved from July 2, 2010, from: www.gcim.org

Parliament of Canada (2001, December). Bill C-36. Author. Retrieved July 3, 2010, from http://www2.parl.gc.ca/HousePublications/Publication.aspx?DocId=2330951\&Language=e\&Mo $\mathrm{de}=1$

Poelemans, M., \& De Séze, S. (2000). The regularisation of clandestine immigrants in France. European Journal of Migration \& Law, 2(3/4), 309-336.

Preston, J. (2009, April 8). Obama to push immigration bill as one priority. New York Times. Retrieved June 23, 2009, from http:/www.nytimes.com/2009/04/09/us/politics/09immig.html

Reichel, D. (2009). Slovak Republic. In Martin Baldwin-Edwards \& Albert Kraler (Eds), REGINE Regularisations in Europe: Study on practices in the area of regularisation of illegally staying third-country nationals in the Member States of the EU. Appendix B: Country profiles of $22 \mathrm{EU}$ Member States and the USA (pp. 127-131). Vienna: ICMPD. Retrieved from July 10, 2010, from http://research.icmpd.org/1184.html

Reyneri, E. (2001). Migrants' involvement in irregular employment in the Mediterranean countries of the European Union [online]. Geneva: International Labour Organization.

www.ilo.org/public/english/protection/migrant/download/imp/imp4l.pdf

Robertson, G. (2005, May 30). Canada has no handle on illegal immigrant workers. Edmonton Journal, A5.

Robinson, W. G. (1983). Illegal migrants in Canada. Employment and Immigration Canada (Dept.) (Ed.), A report to the honourable Lloyd Axworthy Minister of employment and immigration on illegal migrants in Canada. Ottawa: Employment and Immigration Canada.

Robinson, W. G. (1984). Illegal immigrants in Canada: Recent developments. International Migration Review, 18(3), 474-485.

Ruspini, P. (2009). Italy. In Martin Baldwin-Edwards \& Albert Kraler (Eds), REGINE Regularisations in Europe: Study on practices in the area of regularisation of illegally staying third-country nationals in the Member States of the EU. Appendix A: Country studies (pp. 70-82). Vienna: ICMPD. Retrieved from July 10, 2010, from http://research.icmpd.org/1184.html

Santos, O. (2005). Undocumented workers-an issue of particular relevance to Canadian residents of Portuguese origin. Portuguese Canadian National Congress.

Showler, P. (2007). Bridging the Grand Canyon: Deciding refugee claims. Queen's Quarterly, 114(1), 29.

Showler, P. (2009, September). Fast, fair and final: Reforming Canada's refugee system. The Maytree Foundation. Retrieved November 2, 2009, from http://www.maytree.com 
Showler, P. (2010, March 30). Proposed refugee reforms may be a step towards a faster, fairer system. The Maytree Foundation. Retrieved July 15, 2010, from http:/www.maytree.com

Simich, L. (2006). Hidden meanings of health security: Migration experiences and systemic barriers to mental well-being among non-status migrants in Canada. International Journal of Migration, Health and Social Care, 2(3), 16-27.

Simich, L., Wu, F., \& Nerad, S. (2007). Status and health security: An exploratory study of irregular immigrants in Toronto. Canadian Journal of Public Health, 98(5), 369-373.

Standing Committee on Citizenship and Immigration. (2009). Temporary foreign workers and non-status workers; Seventh report. Ottawa, ON: Communications Publishing Canada.

Soave Strategy Group (SSG) (2006). The impact of undocumented workers on the residential construction industry in the GTA. Toronto: SSG, Prepared for: Laborers' International Union of North America (LIUNA).

Sohler, K. (2009). France. In Martin Baldwin-Edwards \& Albert Kraler (Eds), REGINE Regularisations in Europe: Study on practices in the area of regularisation of illegally staying third-country nationals in the Member States of the EU. Appendix A: Country studies (pp. 1-40). Vienna: ICMPD. Retrieved from July 10, 2010, from http://research.icmpd.org/1184.html

Solidarity Across Borders (n.d.). The four demands of Solidarity Across Borders. Author. Retrieved June 21, 2010, from http://www.solidarityacrossborders.org/en/demands

SOPEMI. 1989. Comparative analysis of regularisation experience in France, Italy, Spain and the United States. In Continuous reporting system on migration (pp.65-101). Paris: OECD.

Sunderhaus, S. (2007). Survey/Data regularization programs for undocumented migrants. Migration Letters, 4(1), 65-76.

Taylor, L. (2009, April 22). Girl faces exile with mom; But community rallies to defend hard-working woman who is raising a model citizen'. Toronto Star, GT.1. Retrieved June 3, 2010, from Canadian Newsstand Major Dailies.

The Globe and Mail (2006, March 28). How to retain workers without a big amnesty. The Globe and Mail, p. A18.

Wöger, A. (2009). United States. In Martin Baldwin-Edwards \& Albert Kraler (Eds), REGINE Regularisations in Europe: Study on practices in the area of regularisation of illegally staying third-country nationals in the Member States of the EU. Appendix B: Country profiles of $22 \mathrm{EU}$ Member States and the USA (pp. 142-146). Vienna: ICMPD. Retrieved from July 10, 2010, from $\mathrm{http}: / /$ research.icmpd.org/1184.html

Wright, C. (2003). Moments of emergence: Organizing by and with undocumented and non-citizen people in Canada after September 11. Refuge, 21(3), 5-15.

Young, J. (2005). 'This is my life': Questions of agency and belonging among youth living with less than full status. Ryerson University, Toronto: Unpublished master's major research paper. 